\title{
CORROSION PERFORMANCE OF PRESTRESSING STRANDS IN CONTACT WITH DISSIMILAR GROUTS
}

By

\author{
Matthew O’Reilly \\ David Darwin \\ JoAnn Browning
}

\begin{abstract}
Research supported by
THE KANSAS DEPARTMENT OF TRANSPORTATION
\end{abstract}

Structural Engineering and Engineering Materials

SL Report 12-1

THE UNIVERSITY OF KANSAS CENTER FOR RESEARCH, INC.

LAWRENCE, KANSAS

April 2012 



\begin{abstract}
To improve the corrosion protection provided to prestressing strands, anti-bleed grouts are used to fill voids in post-tensioning ducts that result from bleeding and shrinkage of older portland cement grouts. Environmental differences caused by exposing the strands to dissimilar grouts, however, have the potential to cause rapid corrosion. Portland cement grout, gypsum grout, and four commercially available prepackaged grouts were analyzed to determine the chemical composition of the resulting pore solutions and tested to determine if using a second grout will provide improved corrosion protection for prestressing strands or result in accelerated corrosion. The potential consequences of leaving the voids unfilled were also evaluated. Pore solutions were analyzed for $\mathrm{pH}$ and sodium, potassium, fluoride, chloride, nitrite, sulfate, carbonate, nitrate, and phosphate ion content. The analyses were used to develop simulated pore solutions. Selected grouts and simulated pore solutions were paired to evaluate their potential to cause corrosion of, respectively, grout-wrapped and bare stress-relieved seven-wire prestressing strands using the rapid macrocell test. Strands were also evaluated in simulated pore solutions containing chlorides and in deionized water. Because exposure of strands to water or chlorides has the potential to cause rapid corrosion, filling voids in post-tensioning ducts with an antibleed grout is recommended. Gypsum grout, with its low pH and high sulfate content, will cause accelerated corrosion of strands when used in conjunction with portland cement grout or any of the commercially prepackaged grouts tested. When paired with portland cement grout, the prepackaged anti-bleed grouts evaluated in this study resulted in corrosion losses significantly below those observed for strands exposed to salt or water. The highest corrosion measured for a prepackaged grout occurred for the grout with the highest pore solution sulfate content.
\end{abstract}

Keywords: chlorides, concrete, corrosion, grout, macrocell, prestressing strands 


\section{ACKNOWLEDGEMENTS}

The research described in this report was supported by the Kansas Department of Transportation. 


\section{INTRODUCTION}

Inspections of post-tensioned bridges by the Kansas Department of Transportation have revealed voids in strand ducts due to bleeding and shrinkage of older portland cement grouts (PB Americas 2010). The Kansas Department of Transportation is faced with a decision whether to fill these voids or to leave them ungrouted. As long as the voids remain dry, the strands typically appear intact with some surface rust. However, field observations indicate that severe corrosion occurs in cases in which water or water containing chlorides comes in contact with the strands.

The usual approach to filling voids in post-tensioning ducts involves using prepackaged anti-bleed grouts. Unfortunately, in a number of cases, the repair operations appear to have led to rapid corrosion of the re-grouted strands. A likely cause of the rapid corrosion is a difference in electrical potential in the strands caused by differences in environment provided by the dissimilar grout.

The dual goals of this study are to (1) determine if using a second grout will provide improved corrosion protection for the prestressing strands or result in accelerated corrosion and (2) determine the possible consequences of leaving the voids unfilled. To accomplish these goals, this research is designed to measure the effect of the differences in the environment provided by different grouts and to compare the level of corrosion caused by filling the voids with an anti-bleed grout to that resulting if the strands are not re-grouted but are subjected to water or water containing chloride.

This study consists of two parts. In the first part, pore solution is extracted from hardened samples of each grout and analyzed to determine differences in chemical composition. In the second part, prestressing strands are tested in either simulated grout pore solutions or in the grouts themselves to determine if the differences in environment provided by the grouts will 
cause corrosion of the strand. To accomplish the second goal, some strands are submerged in deionized water or in simulated grout pore solutions containing 3 percent by weight of $\mathrm{NaCl}$ to evaluate the effects of severe exposure that may arise if the voids are not filled.

Six grouting systems are examined: (1) portland cement grout; (2) NA-50 grout, produced by US Mix (NA); (3) Euco Cable Grout PTX (Euco), produced by Euclid Chemical; (4) SikaGrout 300 PT (Sika) produced by Sika Corp.; (5) Sika grout with Sika FerroGard, a corrosion-reducing admixture (Sika w/FerroGard); and (6) a tile underlayment grout, chosen to simulate a grout with a gypsum content. NA-50, Euco Cable Grout, and SikaGrout 300 PT are prepackaged anti-bleed grouts.

\section{EXPERIMENTAL WORK}

\section{Pore Solution Analysis of Grouts}

Pore solution specimens are cast in a 3.75-in.-long section of 1.5-in. diameter Schedule 40 PVC pipe attached to a nonabsorbent base. The grout is mixed with reverse-osmosis filtered water to minimize any effects of ions in the water supply on readings. Specimens are tightly covered with plastic to minimize evaporation. Specimens are removed from the molds just prior to the extraction of the pore solution. Pore solution is collected by subjecting the hardened grout to 80,000 psi using a pressure vessel (Barneyback and Diamond 1981, O'Reilly et al. 2011). Pore solution is collected from the grout one and seven days after casting. The volume of pore solution that can be collected decreases with age, precluding sampling at later ages.

The mixture proportions used for the pore solution specimens are shown in Table 1. Two water-solids $(\mathrm{w} / \mathrm{s})$ ratios were used for each commercial grout, at the extremes of the "recommended" w/s ratios, 0.25 and 0.31 . Water-solids ratios of 0.35 and 0.27 were used for 
portland cement and gypsum grouts, respectively. At these w/s ratios, only the portland cement grout produced enough pore solution for analysis at seven days, as shown in Table 1. A second series of specimens was cast with a w/s ratio of 0.5 to provide a greater volume of pore solution. At one day, however, the high-w/s ratio specimens made with NA and Euco did not have sufficient strength to allow pore solution to be expressed; the high w/s ratio gypsum grout had insufficient strength at both one and seven days.

Table 1: Water-Solids Ratio and Volume of Pore Solution Collected

\begin{tabular}{|c|c|c|c|c|c|}
\hline \multirow{2}{*}{$\begin{array}{c}\text { Age at } \\
\text { Sampling }\end{array}$} & \multirow[b]{2}{*}{ Grout } & \multicolumn{2}{|c|}{ Recommended w/s } & \multicolumn{2}{|c|}{ High w/s } \\
\hline & & $\mathbf{w} / \mathbf{s}^{\mathrm{a}}$ & $\begin{array}{c}\text { Volume } \\
\text { (mL) }\end{array}$ & $\mathbf{w} / \mathbf{s}$ & $\begin{array}{c}\text { Volume } \\
\text { (mL) }\end{array}$ \\
\hline \multirow{6}{*}{$\frac{\overrightarrow{7}}{-1}$} & Portland Cement & 0.35 & 4.8 & 0.5 & 11.2 \\
\hline & NA & 0.31 & 1.6 & 0.5 & $\mathrm{~b}$ \\
\hline & Sika & 0.25 & 2.8 & 0.5 & 11.8 \\
\hline & Sika w/FerroGard & 0.25 & 2.0 & 0.5 & 6.4 \\
\hline & Euco & 0.25 & $\mathrm{c}$ & 0.5 & $\mathrm{~b}$ \\
\hline & Gypsum Grout & 0.27 & 0.4 & 0.5 & $\mathrm{~b}$ \\
\hline \multirow{6}{*}{$\sum_{0}^{\infty}$} & Portland Cement & 0.35 & 1.3 & 0.5 & 3.2 \\
\hline & NA & 0.31 & c & 0.5 & 2.0 \\
\hline & Sika & 0.25 & $\mathrm{c}$ & 0.5 & 2.9 \\
\hline & Sika w/FerroGard & 0.25 & $\mathrm{c}$ & 0.5 & 1.4 \\
\hline & Euco & 0.25 & $\mathrm{c}$ & 0.5 & 3.4 \\
\hline & Gypsum Grout & 0.27 & $\mathrm{c}$ & 0.5 & $\mathrm{~b}$ \\
\hline
\end{tabular}

${ }^{a}$ Mixed per manufacturer's directions

${ }^{\mathrm{b}}$ Sample did not have sufficient strength to allow for pore solution collection

${ }^{\mathrm{c}}$ Unable to collect enough sample for testing

All pore solutions were analyzed for $\mathrm{pH}$ and sodium, potassium, fluoride, chloride, nitrite, sulfate, carbonate, nitrate, and phosphate ion content. $\mathrm{pH}$ was measured using titration with hydrochloric acid. Sodium and potassium contents were measured using flame emission spectroscopy, while the other ionic species were measured using ion chromatography. Full details of the analysis procedures are described by O'Reilly et al. (2011). 


\section{Rapid Macrocell Testing of Post-Tensioning Strand}

The potential for dissimilar grouts to induce corrosion in post-tensioning strands is evaluated using a modified version of the rapid macrocell test, a corrosion performance test developed at the University of Kansas ( $\mathrm{Ji}$ et al. 2005). The rapid macrocell test is described in ASTM A955 and is used to qualify stainless steel reinforcement. It has, however, been used evaluate the corrosion performance of a wide variety of reinforcing steels (Ji et al. 2005, Sturgeon et al. 2010, Xing et al. 2010, O’Reilly et al. 2011).

In this study, ASTM A416 low-relaxation seven-wire strands are tested in both the bare (Figure 1a) and grout-wrapped (Figure 1b) conditions. Each post-tensioning strand used in the rapid macrocell test is $10 \mathrm{in}$. long. The strand is cleaned with acetone prior to testing to remove any surface contaminants. A length of 16-gauge insulated copper wire is attached to the strand at the gaps between the wires. The electrical connection is coated with epoxy and a 3-in. length of heat-shrink tubing to protect the wire from corrosion. Grout-wrapped strand is encased in grout to a depth of 8 in. with 0.5 in. cover over the bottom of the strand, for a total grout length of 8.5 in.

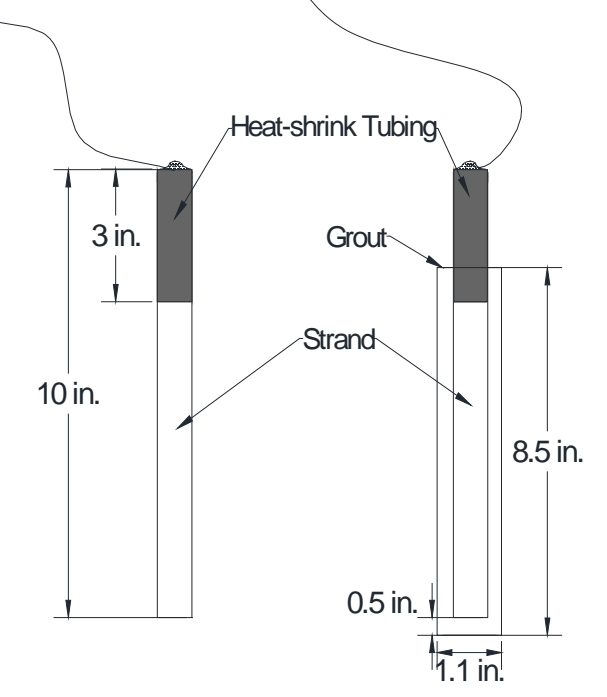

(a)

(b)

Figure 1 - Rapid macrocell test specimen. (a) bare strand, (b) grout-wrapped strand 
The grout has a nominal diameter of 1.1 in.

Two strands are used in each rapid macrocell test. The strands are submerged in different simulated grout solutions, as shown in Figures 2 and 3 for bare and grout-wrapped specimens, respectively. Bare strands are submerged to a depth of 3 in., while grout-wrapped strands are submerged to a depth of $3.5 \mathrm{in}$. to adjust for the 0.5 -in. grout cover beneath the strand. The pore solution compositions used in the rapid macrocell test are based on the results of the pore solution analyses. The grout-wrapped specimens are submerged in the simulated pore solutions matching the grout. The compositions of the pore solutions are listed in Table 2 (the basis for the solutions is presented in the Results section). Solutions are changed every five weeks to limit carbonation from atmospheric carbon dioxide.

Most specimens were tested for fifteen weeks. For grout-wrapped specimens, however, all specimens with the exception of the G/SFG (Gypsum Grout/Sika with FerroGard) series were tested for thirty weeks to allow for the collection of additional data.

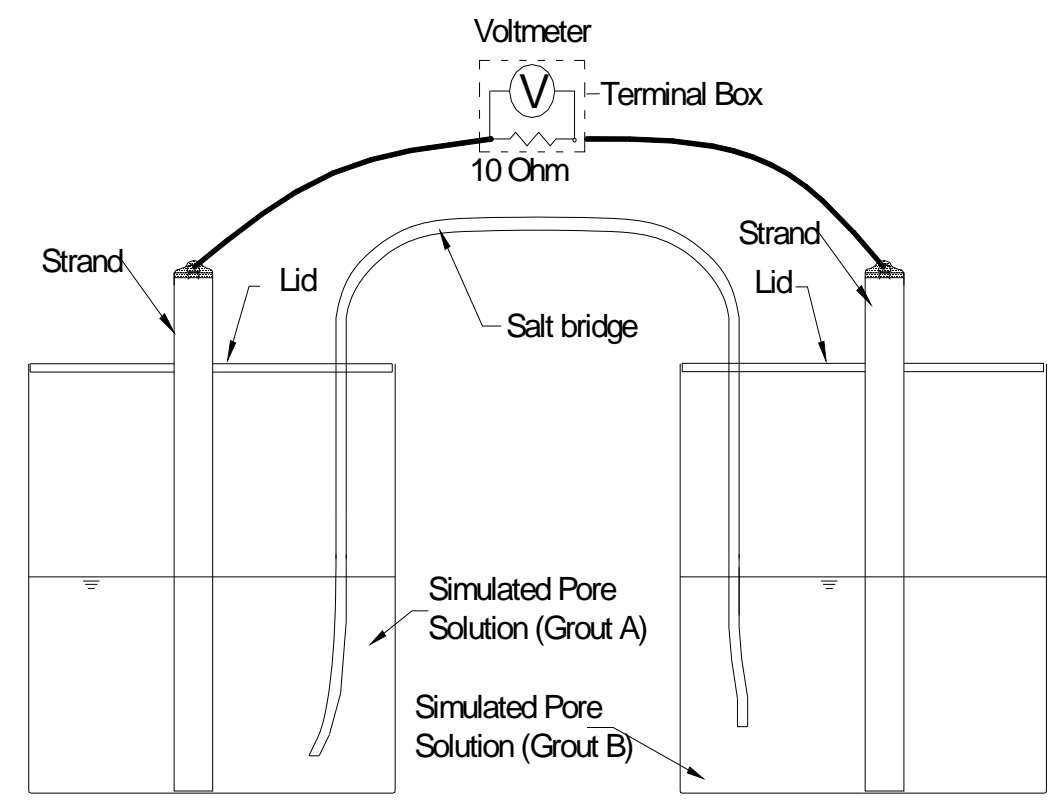

Figure 2 - Rapid macrocell test setup for bare prestressing strand. 


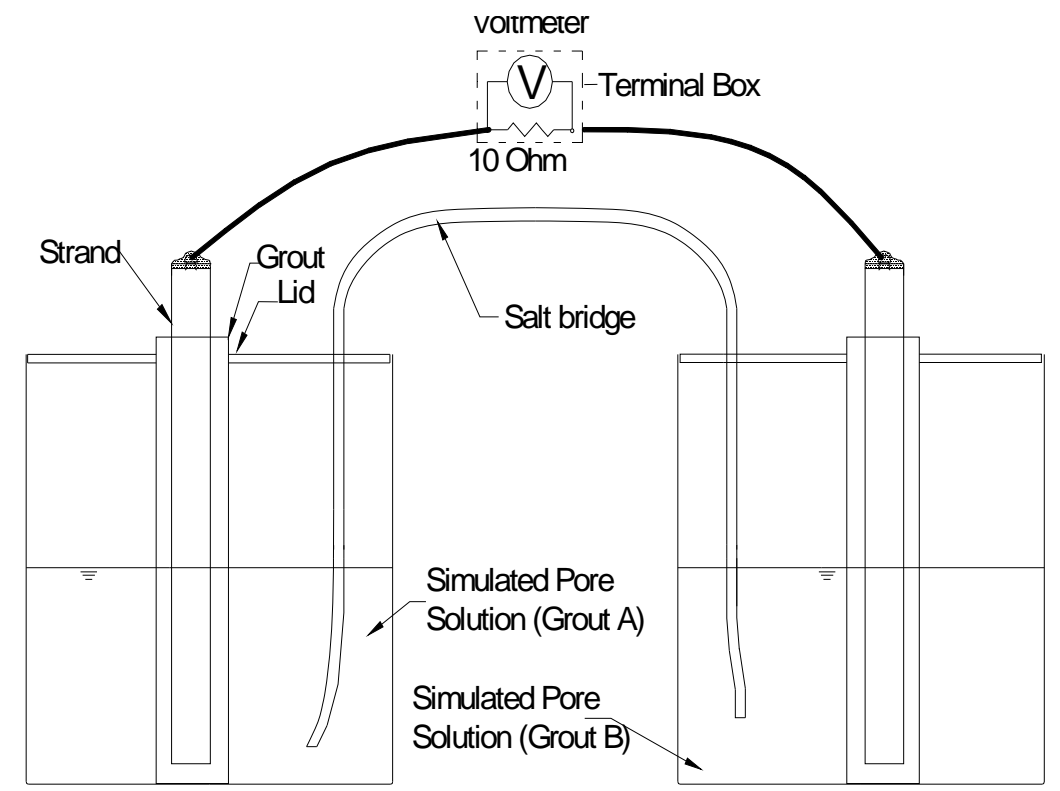

Figure 3 - Rapid macrocell test setup for grout-wrapped prestressing strand.

Table 2: Mix Quantities (s) for 1 Liter of Simulated Pore Solution

\begin{tabular}{|l|c|c|c|c|c|c|}
\hline \multirow{2}{*}{ Grout } & \multicolumn{7}{c|}{ Mix per liter (g) } \\
\cline { 2 - 7 } & $\mathbf{N a O H}$ & $\mathbf{K O H}$ & $\mathbf{N a}_{2} \mathbf{S O}_{\mathbf{4}}$ & $\mathbf{N a}_{3} \mathbf{P O}_{4}$ & $\mathbf{N a}_{2} \mathbf{C O}_{3}$ & $\mathbf{H}_{\mathbf{2}} \mathbf{O}$ \\
\hline Portland Cement & 7.45 & 8.99 & 0.66 & - & - & 982.9 \\
\hline NA & 6.80 & 11.28 & 1.93 & - & - & 980.0 \\
\hline Sika & 7.60 & 6.28 & 0.45 & - & - & 985.7 \\
\hline Sika w/FerroGard & 22.73 & 21.66 & 0.29 & 10.72 & - & 944.6 \\
\hline Euco & 7.21 & 2.45 & 0.60 & - & - & 989.7 \\
\hline Gypsum Grout & 2.58 & 1.98 & 1.29 & - & 2.26 & 991.9 \\
\hline
\end{tabular}

The two strands in each test are electrically connected across a 10-ohm resistor, and the solutions are ionically connected with a potassium nitrate salt bridge. The salt bridge is fabricated as described in ASTM A955, except $41 \mathrm{~g}$ of potassium nitrate are used in place of the $30 \mathrm{~g}$ potassium chloride specified in ASTM A955. The change in solute in the salt bridge is made to avoid the risk of chlorides leeching into the pore solution. The corrosion rate is calculated based on the voltage drop across the 10-ohm resistor. Dividing the voltage drop by resistance gives the current flow; dividing by the surface area of the steel $\left(13.1 \mathrm{in}^{2}\left[84.3 \mathrm{~cm}^{2}\right]\right.$, 
the surface area of a 3 in. length for the seven individual wires in the strand) gives the corrosion current density. Using Faraday’s equation,

$$
\text { Rate }=K \frac{i \cdot m}{n \cdot F \cdot D}
$$

where the Rate is given in $\mu \mathrm{m} / \mathrm{yr}$, and

$$
\begin{aligned}
& K=\text { conversion factor }=31.5 \cdot 10^{4} \mathrm{amp} \cdot \mu \mathrm{m} \cdot \mathrm{sec} / \mu \mathrm{A} \cdot \mathrm{cm} \cdot \mathrm{yr} \\
& i=\text { corrosion current density, } \mu \mathrm{A} / \mathrm{cm}^{2} \\
& m=\text { atomic weight of the metal (for iron, } m=55.8 \mathrm{~g} / \mathrm{g} \text {-atom) } \\
& n=\text { number of ion equivalents exchanged (for iron, } n=2 \text { equivalents) } \\
& F=\text { Faraday's constant }=96,485 \text { coulombs } / \text { equivalent } \\
& D=\text { density of the metal, } \mathrm{g} / \mathrm{cm}^{3} \text { (for iron, } D=7.87 \mathrm{~g} / \mathrm{cm}^{3} \text { ) } \\
& \text { Using the values listed above, the corrosion rate simplifies to } \\
& \text { Rate }=11.6 i
\end{aligned}
$$

In addition to the corrosion rate, the corrosion potentials of the strands are measured with respect to a saturated calomel electrode (SCE). Readings are taken daily for seven days and weekly thereafter. In addition, the corrosion rate of each specimen is also measured using linear polarization resistance (LPR) every three weeks.

Linear polarization resistance provides a means to measure combined microcell and macrocell corrosion (only the latter is measured by the voltage drop across the 10 -ohm resistor) by measuring its response to an applied voltage (polarization). This allows for a more complete picture of corrosion activity; for example, corrosion occurring evenly on strands in both pore solutions in a rapid macrocell test will result in very little net current flow, but will yield a measureable corrosion rate for each strand via LPR. 
With no externally applied voltage, a metal will corrode with a current density $i$ and a potential $E_{\text {corr }}$. Forcing the potential to shift by an amount $\Delta \varepsilon$ will cause the current to shift by some amount $\Delta i$. The polarization resistance is defined as the slope of the potential-current function, also known as the polarization curve (Jones 1996).

$$
R_{p}=\left[\frac{\Delta \varepsilon}{\Delta i}\right]_{t \rightarrow 0}
$$

where

$R_{p}=$ polarization resistance

$\Delta \varepsilon=$ imposed potential change

$\Delta i=$ current density change caused by $\Delta \varepsilon$

For small changes in potential, the polarization curve is linear. In this region, the polarization resistance is inversely proportional to the corrosion current density.

$$
i=\frac{\beta_{a} \beta_{b}}{2.3 R_{p}\left(\beta_{a}+\beta_{b}\right)}
$$

where

$\beta_{a}, \beta_{c}=$ anodic and cathodic Tafel constants, $\mathrm{V} /$ decade

The polarization resistance may be determined by taking a series of current density measurements at a range of potential shifts and measuring the resultant current, or by applying a range of currents to the sample and measuring the resultant voltage shifts. Plotting the data and finding the slope of the linear region yields $R_{p}$ [Eq. (3)]. The corrosion current density may then be found using Eq. (4). Values of $0.12 \mathrm{~V} /$ decade for both of the anodic and cathodic Tafel constants $\beta_{a}$ and $\beta_{c}$ have been suggested for reinforcing steel in concrete (Lambert, Page, and Vassie 1991, McDonald, Pfeifer, and Sherman 1998) and are used in this study. Using these values in Eq. (4) yields 


$$
i=\frac{0.026}{R_{p}}
$$

With the current density known, the corrosion rate may be obtained using Eq. (2).

Overall, the macrocell corrosion results provide a measure of the effect of exposing prestressing strands to different environments that result from using dissimilar grouts, while the LPR results provide a measure of total corrosion losses.

The rapid macrocell test program is summarized in Table 3. Four test regimes were used: (1) bare strands in simulated grout pore solution; (2) grout-wrapped strands in simulated grout pore solution; (3) bare strands with one of the strands submerged in deionized water and the other in simulated grout pore solution; and (4) bare strands in simulated grout pore solutions containing 3 percent by weight of $\mathrm{NaCl}$ in both solutions.

Table 3: Rapid Macrocell Test Program

\begin{tabular}{|c|c|c|}
\hline Test Regimes & System Designation $^{\mathrm{a}, \mathrm{b}}$ & $\begin{array}{c}\text { Test } \\
\text { Duration } \\
\text { (weeks) }\end{array}$ \\
\hline \multirow{6}{*}{ Bare strand } & G/SFG & 15 \\
\hline & G/PC & 15 \\
\hline & Euco/PC & 15 \\
\hline & NA/PC & 15 \\
\hline & S/PC & 15 \\
\hline & SFG/PC & 15 \\
\hline \multirow{3}{*}{$\begin{array}{l}\text { Grout wrapped } \\
\text { in pore solution }\end{array}$} & G/SFG-GW & 15 \\
\hline & S/PC-GW & 30 \\
\hline & SFG/PC-GW & 30 \\
\hline Water & $\mathrm{H}_{2} \mathrm{O} / \mathrm{PC}$ & 15 \\
\hline \multirow{2}{*}{$\begin{array}{c}\text { Bare strand in } \\
\text { pore solution } \\
\text { w/salt }\end{array}$} & NA/PC (w/salt) & 15 \\
\hline & SFG/PC (w/salt) & 15 \\
\hline
\end{tabular}

${ }^{\mathrm{a}} \mathrm{Six}$ tests each

${ }^{\mathbf{b}} \mathrm{G}=$ gypsum grout, $\mathrm{PC}=$ portland cement, Euco $=$ Euco

Cable Grout PTX, NA = NA-50 grout, $\mathrm{S}=$ SikaGrout 300

PT, $\mathrm{SFG}=$ SikaGrout 300 PT with FerroGard, $\mathrm{H}_{2} \mathrm{O}=$

deionized water. 


\section{RESULTS}

\section{Pore Solution Analysis of Grouts}

The $\mathrm{pH}$ values for the pore solutions are presented in Tables 4 and 5 for the grouts with the recommended and high w/s ratios, respectively. In the four cases where samples could be obtained at both ages, $\mathrm{pH}$ increased between day 1 and day 7 . The $\mathrm{pH}$ values of the grouts mixed at the recommended and high $\mathrm{w} / \mathrm{s}$ ratios are similar. Of the six grouts analyzed, all had a $\mathrm{pH}$ above 13.35, with the exception of the gypsum grout, which had a pH of 13.0.

Table 4: $\mathrm{pH}$ of Pore Solutions for Grouts with Manufacturer's Recommended w/s Ratios

\begin{tabular}{|l|c|c|c|}
\hline \multirow{2}{*}{ Grout } & \multirow{2}{*}{ w/s } & \multicolumn{2}{c|}{$\mathbf{p H}$} \\
\cline { 3 - 4 } & & $\mathbf{1}$ day & $\mathbf{7}$ days \\
\hline Portland Cement & 0.35 & 13.48 & 13.63 \\
\hline NA & 0.31 & 13.57 & $\mathrm{~b}$ \\
\hline Sika & 0.25 & 13.54 & $\mathrm{~b}$ \\
\hline Sika w/FerroGard & 0.25 & 13.80 & $\mathrm{~b}$ \\
\hline Euco & 0.25 & $\mathrm{~b}$ & $\mathrm{~b}$ \\
\hline Gypsum & 0.27 & 13.00 & $\mathrm{~b}$ \\
\hline
\end{tabular}

${ }^{\mathrm{a}}$ Mixed per manufacturer's directions

${ }^{\mathrm{b}}$ Unable to collect enough sample for testing

Table 5: $\mathrm{pH}$ of Pore Solutions for Grouts with w/s Ratio $=0.5$

\begin{tabular}{|l|c|c|c|}
\hline \multirow{2}{*}{\multicolumn{1}{c|}{ Grout }} & \multirow{2}{*}{ w/s } & \multicolumn{2}{c|}{$\mathbf{p H}$} \\
\cline { 3 - 4 } & & $\mathbf{1}$ day & $\mathbf{7}$ days \\
\hline Portland Cement & 0.5 & 13.48 & 13.54 \\
\hline NA & 0.5 & $\mathrm{a}$ & 13.57 \\
\hline Sika & 0.5 & 13.40 & 13.48 \\
\hline Sika w/FerroGard & 0.5 & 13.89 & 13.98 \\
\hline Euco & 0.5 & ${ }^{\mathrm{a}}$ & 13.35 \\
\hline Gypsum & 0.5 & ${ }^{\mathrm{a}}$ & $\mathrm{a}$ \\
\hline
\end{tabular}

${ }^{a}$ Sample did not have sufficient strength to allow for pore solution collection

The ionic concentrations in parts per million (ppm) are presented in Tables 6 and 7 for the grouts with the recommended and high w/s ratios, respectively. The concentrations of fluoride, 
Table 6: Ionic Concentrations (ppm) of Pore Solutions for Grouts with Manufacturer's Recommended w/s Ratios

\begin{tabular}{|c|c|c|c|c|c|c|c|c|c|c|c|}
\hline & Grout & $w / s^{a}$ & Fluoride & Chloride & Nitrite & Carbonat & Sulfat & Nitrate & Phosphate & Sodium & Potassium \\
\hline \multirow{6}{*}{$\frac{3}{d}$} & Portland Cement & 0.35 & 0 & 222 & 82 & 12 & 344 & 13 & 13 & 5189 & 8787 \\
\hline & NA & 0.31 & 0 & 271 & 535 & 0 & 1538 & 13 & 2 & 5236 & 14055 \\
\hline & Sika & 0.25 & 158 & 188 & 174 & 23 & 431 & 7 & 1 & 6683 & 9611 \\
\hline & Sika w/FerroGard & 0.25 & 40 & 34 & 276 & 32 & 45 & 6 & 3388 & 5575 & 6128 \\
\hline & Euco & 0.25 & & & & & $\mathrm{~b}$ & & & & \\
\hline & Gypsum & 0.27 & 64 & 0 & 0 & 1278 & 870 & 0 & 44 & 4986 & 3539 \\
\hline \multirow{6}{*}{ 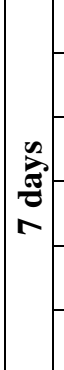 } & Portland Cement & 0.35 & 27 & 268 & 80 & 57 & 489 & 0 & 17 & 7684 & 13824 \\
\hline & NA & 0.31 & & & & & $\mathrm{~b}$ & & & & \\
\hline & Sika & 0.25 & & & & & $\mathrm{~b}$ & & & & \\
\hline & Sika w/FerroGard & 0.25 & & & & & $\mathrm{~b}$ & & & & \\
\hline & Euco & 0.25 & & & & & $\mathrm{~b}$ & & & & \\
\hline & Gypsum & 0.27 & & & & & $\mathrm{~b}$ & & & & \\
\hline
\end{tabular}

${ }^{a}$ Mixed per manufacturer's directions

${ }^{\mathrm{b}}$ Unable to collect enough sample for testing

Table 7: Ionic Concentrations (ppm) of Pore Solutions for Grouts with w/s Ratio $=0.5$

\begin{tabular}{|c|c|c|c|c|c|c|c|c|c|c|c|}
\hline & Grout & $w / s$ & Fluorid & hloride & Nitrite & Carbonat & Sulfate & Nitrate & Phosphate & Sodium & Potassium \\
\hline \multirow{6}{*}{$\vec{z}$} & Portland Cement & 0.5 & 0 & 142 & 66 & 4 & 133 & 3 & 7 & 4190 & 6320 \\
\hline & NA & 0.5 & \multicolumn{9}{|c|}{$\mathrm{a}$} \\
\hline & Sika & 0.5 & 123 & 83 & 44 & 4 & 15 & 3 & 1 & 4243 & 4624 \\
\hline & Sika w/FerroGard & 0.5 & 0 & 78 & 62 & 4 & 15 & 4 & 4287 & 5881 & 5239 \\
\hline & Euco & 0.5 & \multicolumn{9}{|c|}{ a } \\
\hline & Gypsum & 0.5 & \multicolumn{9}{|c|}{ a } \\
\hline \multirow{6}{*}{ 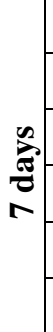 } & Portland Cement & 0.5 & 84 & 13 & 0 & 357 & 445 & 12 & 42 & 5622 & 7550 \\
\hline & NA & 0.5 & 319 & 39 & 0 & 236 & 1306 & 9 & 24 & 5827 & 9389 \\
\hline & Sika & 0.5 & 30 & 41 & 0 & 210 & 305 & 4 & 2 & 6493 & 6105 \\
\hline & Sika w/FerroGard & 0.5 & 65 & 0 & 0 & 489 & 196 & 15 & 6211 & 6087 & 6757 \\
\hline & Euco & 0.5 & 481 & 88 & 9 & 460 & 405 & 0 & 17 & 6600 & 2304 \\
\hline & Gypsum & 0.5 & \multicolumn{9}{|c|}{ a } \\
\hline
\end{tabular}

${ }^{a}$ Sample did not have sufficient strength to allow for pore solution collection

chloride, nitrite, and nitrate are below (in most cases well below) $300 \mathrm{ppm}$, with the exception of $\mathrm{NA}, \mathrm{w} / \mathrm{s}$ ratio $=0.31$ at one day $($ nitrite $=535 \mathrm{ppm}), \mathrm{NA}, \mathrm{w} / \mathrm{s}$ ratio $=0.50$ at seven days (fluoride 
$=319 \mathrm{ppm})$, and Euco, w/s ratio $=0.50$ at seven days $($ fluoride $=481 \mathrm{ppm})$. The gypsum grout with a w/s ratio of 0.5 exhibits elevated carbonate levels at one day (Table 6), the only age for which a pore solution sample could be collected from a gypsum grout. Other grouts have negligible carbonate concentrations.

All grouts have sulfate concentrations on the order of hundreds of ppm, with the exception of Sika w/FerroGard at one day at the recommended w/s ratio (Table 6) and Sika and Sika w/FerroGard at one day with the high w/s ratio (Table 7), which has sulfate concentrations below $45 \mathrm{ppm}$. NA grout has the highest sulfate concentrations, over $1300 \mathrm{ppm}$ in both the recommended w/s ratio mix at one day and the high w/s ratio mix at seven days, while the gypsum grout has a value of $870 \mathrm{ppm}$ at one day. The sulfate concentration is of interest because sulfate, like chloride, reduces the passive protection provided by the alkaline environment provided by cementitious materials (Al-Amoudi et al. 1994, Turkman and Gavgali 2003, AlAmoudi 2007, Shi and Sun 2011). The combination of high sulfate content and low pH for the gypsum grout pore solution indicates potential for reduced corrosion protection.

Sika w/FerroGard has extremely high phosphate levels at all ages and w/s ratios.

With exception of the gypsum grout, the simulated pore solutions used in the rapid macrocell tests were based on the 7-day $0.5 \mathrm{w} / \mathrm{s}$ ratio results because that series was the most complete (lacking only gypsum grout results). The results at one day a w/s ratio of 0.27 (the only data available) were used for the gypsum grout pore solution. The quantities used for 1 liter of simulated pore solution are presented in Table 2 . 


\section{Rapid Macrocell Testing of Post-Tensioning Strand}

\section{Bare Strand}

The average macrocell corrosion rates for bare prestressing strand in the simulated grout pore solutions are shown in Figure 4; individual corrosion losses at 15 weeks are listed in Table 8. Systems are listed in pairs. For example, G/SFG indicates one strand in the macrocell is in simulated gypsum grout pore solution $(G)$ while the other is in simulated Sika grout with Ferrogard pore solution (SFG). Positive corrosion rates and losses indicate that the strand in the first pore solution in the pair is corroding more rapidly than the second; negative rates and losses indicate that the strand in the pore solution listed second is corroding more rapidly.

All specimens have average macrocell corrosion rates of less than $1.5 \mu \mathrm{m} / \mathrm{yr}$ for the first two weeks of testing. After week 2, the corrosion rates of G/SFG and G/PC increase sharply, with both systems showing corrosion on the strand in simulated gypsum grout pore solution. The G/PC specimens have a peak corrosion rate of $19.3 \mu \mathrm{m} / \mathrm{yr}$ at week 5 before the corrosion rate drops to about $5 \mu \mathrm{m} / \mathrm{yr}$, where it remains for the remainder of the test. The corrosion rate of G/SFG specimens gradually increases throughout the test, reaching a peak of $6.79 \mu \mathrm{m} / \mathrm{yr}$ at week 14 (Figure 4a). All other specimens exhibit macrocell corrosion rates below $1 \mu \mathrm{m} / \mathrm{yr}$ throughout testing (Figure 4b).

After 15 weeks, the G/PC specimens have the greatest average macrocell corrosion loss, $1.40 \mu \mathrm{m}$ (Table 8 ), followed by the G/SFG specimens with an average loss of $0.933 \mu \mathrm{m}$. The NA/PC specimens have an average corrosion loss of $0.107 \mu \mathrm{m}$. All other specimens have average corrosion losses below $0.1 \mu \mathrm{m}$ at 15 weeks. 


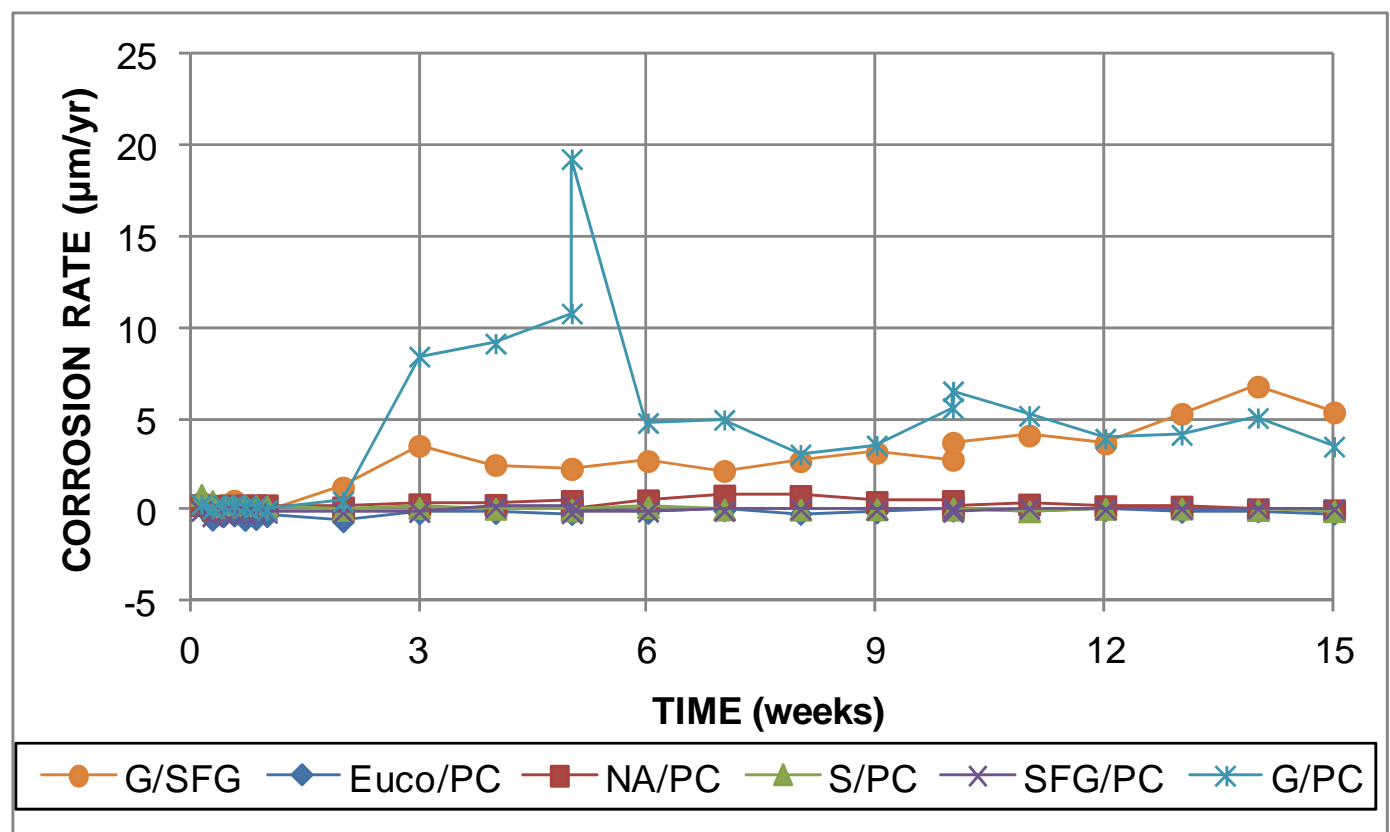

Figure 4a: Average macrocell corrosion rates for bare strand in simulated grout solution.

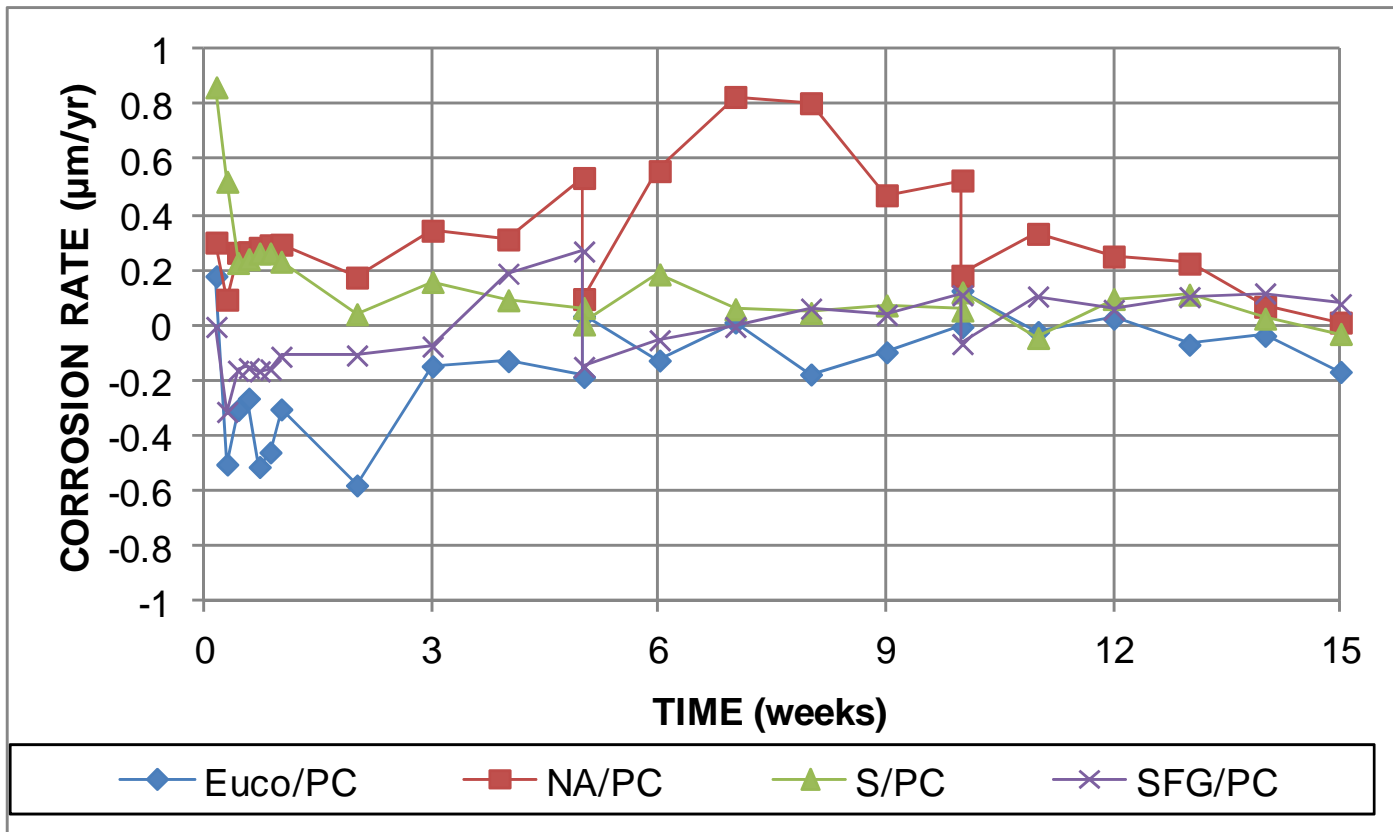

Figure 4b: Average macrocell corrosion rates for bare strand in simulated grout solution (different scale). 
Table 8: Macrocell Corrosion Losses $(\mu \mathrm{m})$ at 15 Weeks for Bare Prestressing Strand in Simulated Pore Solution

\begin{tabular}{|c|c|c|c|c|c|c|c|c|}
\hline \multirow{2}{*}{ System $^{a}$} & \multicolumn{6}{|c|}{ Specimen } & \multirow{2}{*}{ Average } & \multirow{2}{*}{$\begin{array}{l}\text { Standard } \\
\text { Deviation }\end{array}$} \\
\hline & 1 & 2 & 3 & 4 & 5 & 6 & & \\
\hline G/SFG & 0.359 & 0.625 & 1.45 & 0.599 & 0.927 & 1.64 & 0.933 & 0.509 \\
\hline G/PC & 1.36 & 1.33 & 1.31 & 1.27 & 1.50 & 1.64 & 1.40 & 0.140 \\
\hline Euco/PC & 0.020 & -0.005 & -0.001 & -0.198 & -0.030 & -0.017 & $\begin{array}{l}-0.039 \\
\end{array}$ & 0.080 \\
\hline NA/PC & -0.018 & -0.042 & 0.253 & 0.287 & -0.025 & 0.200 & 0.109 & 0.153 \\
\hline S/PC & -0.021 & 0.088 & 0.085 & 0.008 & 0.248 & 0.020 & 0.071 & 0.097 \\
\hline SFG/PC & 0.025 & 0.022 & 0.114 & -0.004 & -0.093 & 0.020 & 0.014 & 0.066 \\
\hline
\end{tabular}

${ }^{\text {a }} \mathrm{PC}=$ portland cement, $\mathrm{G}=$ gypsum, Euco $=$ Euco Cable Grout, $\mathrm{S}=$ Sika, $\mathrm{SFG}=$ Sika $\mathrm{w} /$ FerroGard, NA = US Mix NA-50.

Figures 5a-5f show the average corrosion potentials for the bare strands in simulated pore solutions. For the G/SFG (Figure 5a) and G/PC (Figure 5b) specimens, the potential of the strands in the gypsum grout pore solution falls to between -0.25 and $-0.45 \mathrm{~V}$, significantly more negative than the potential of the strand in the other (SFG or PC) pore solution, suggesting active corrosion on the strand in the gypsum pore solution. The corrosion potential of all other systems becomes progressively less negative throughout the test, becoming less negative than $-0.20 \mathrm{~V}$ after 2 to 7 weeks of testing. This correlates well with the low corrosion rates observed for these specimens. 


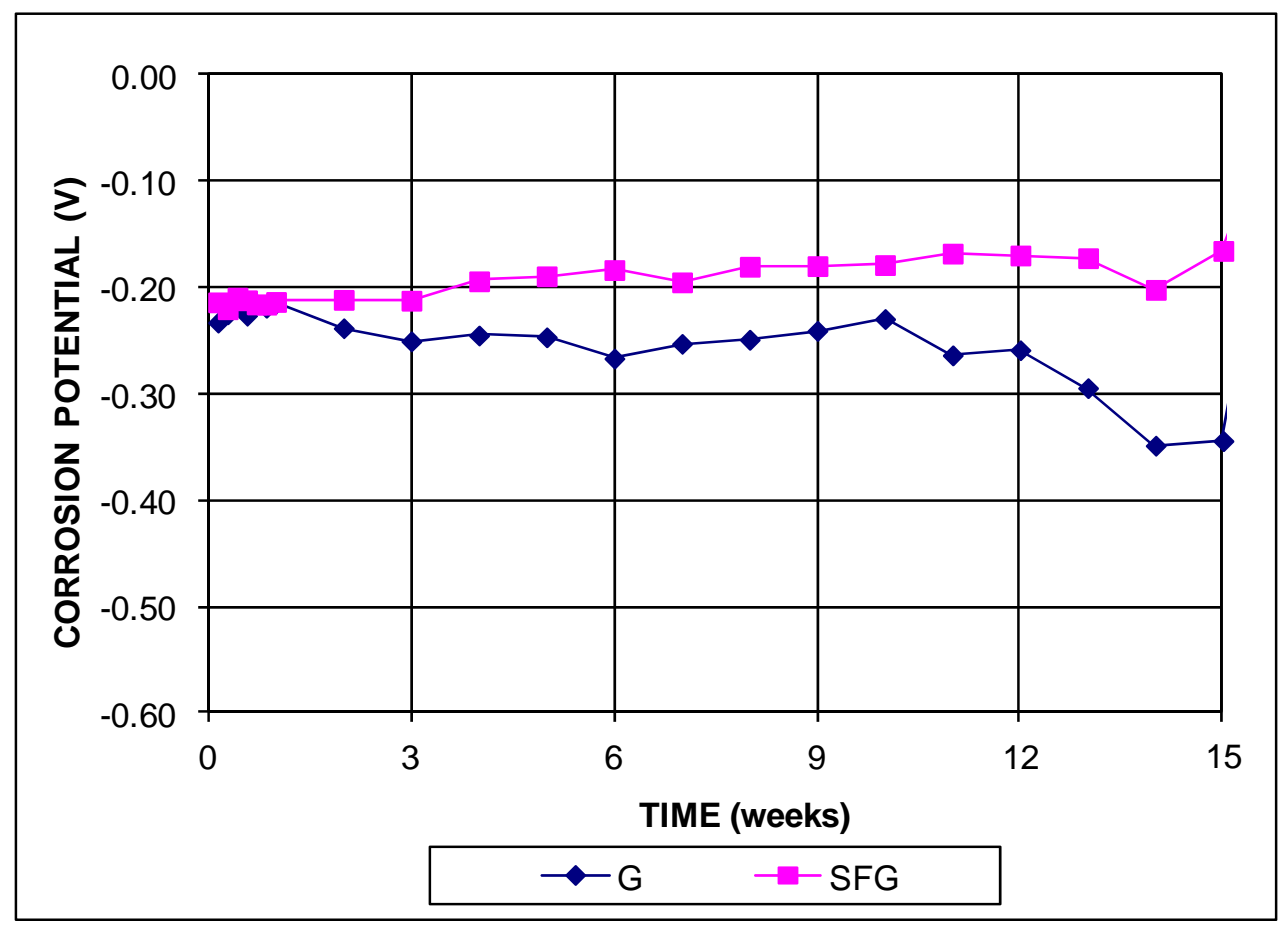

Figure 5a: Average corrosion potential (SCE) for bare prestressing strand in simulated gypsum and Sika w/FerroGard grout pore solutions.

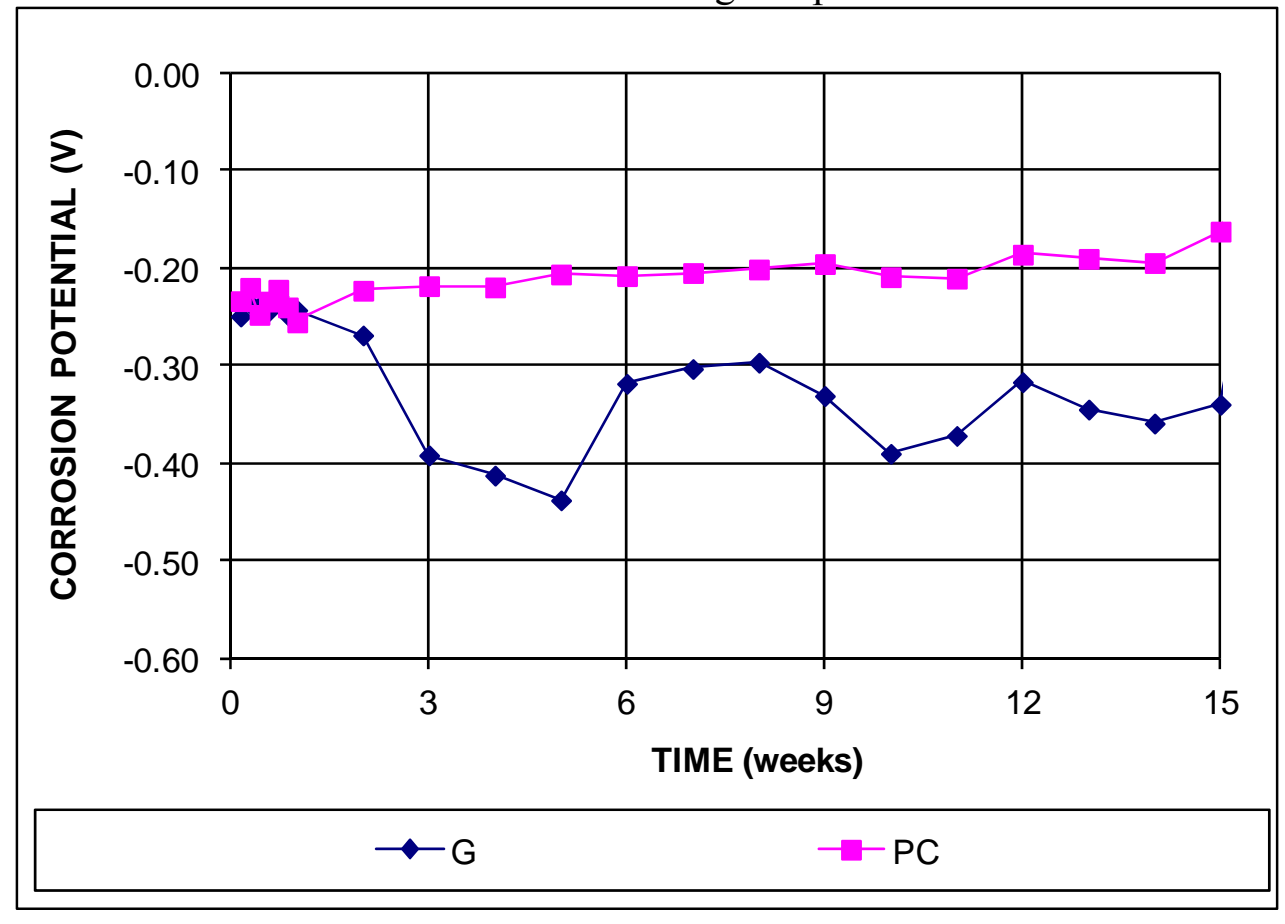

Figure 5b: Average corrosion potential (SCE) for bare prestressing strand in simulated gypsum and portland cement grout pore solutions. 


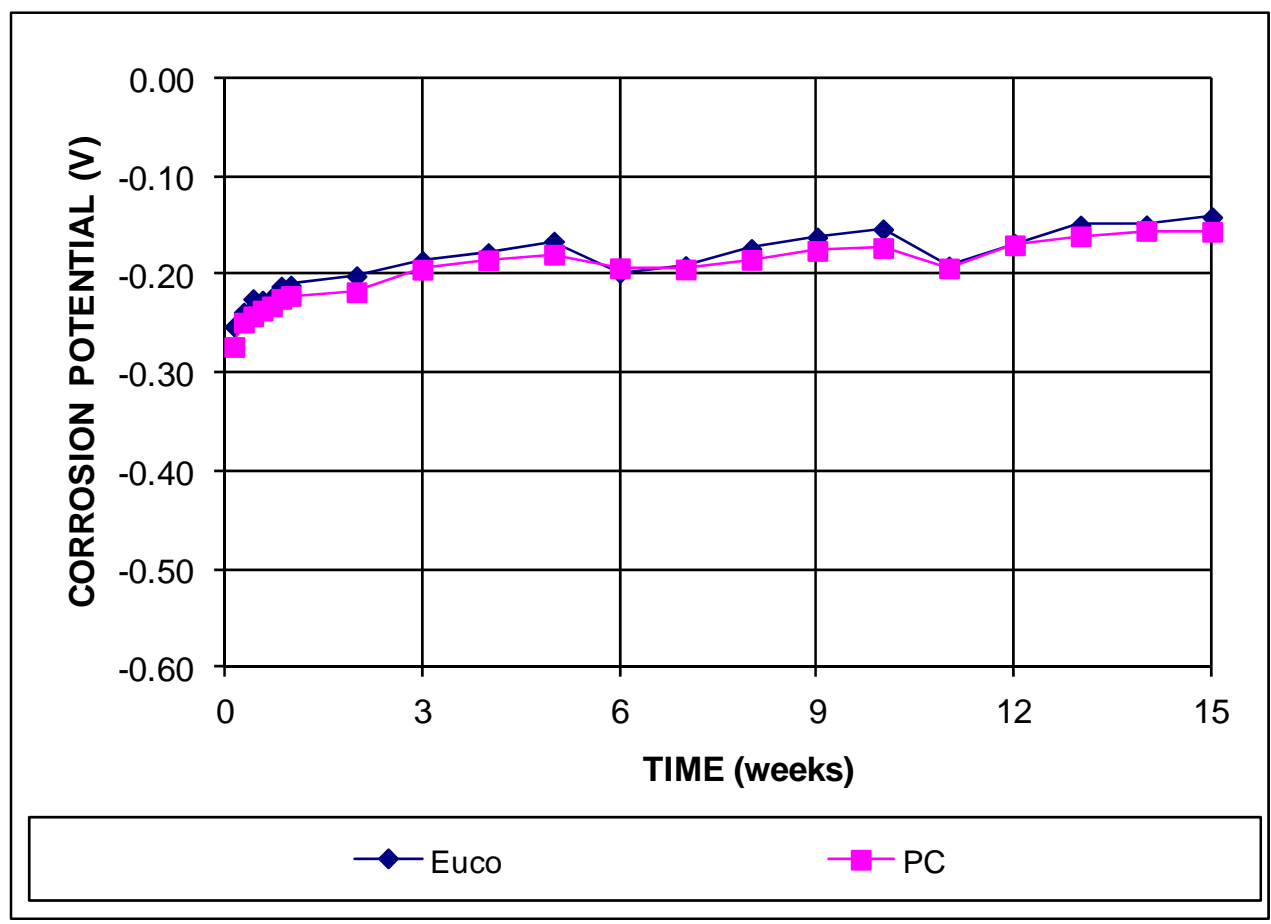

Figure 5c: Average corrosion potential (SCE) for bare prestressing strand in simulated Euco and portland cement grout pore solutions.

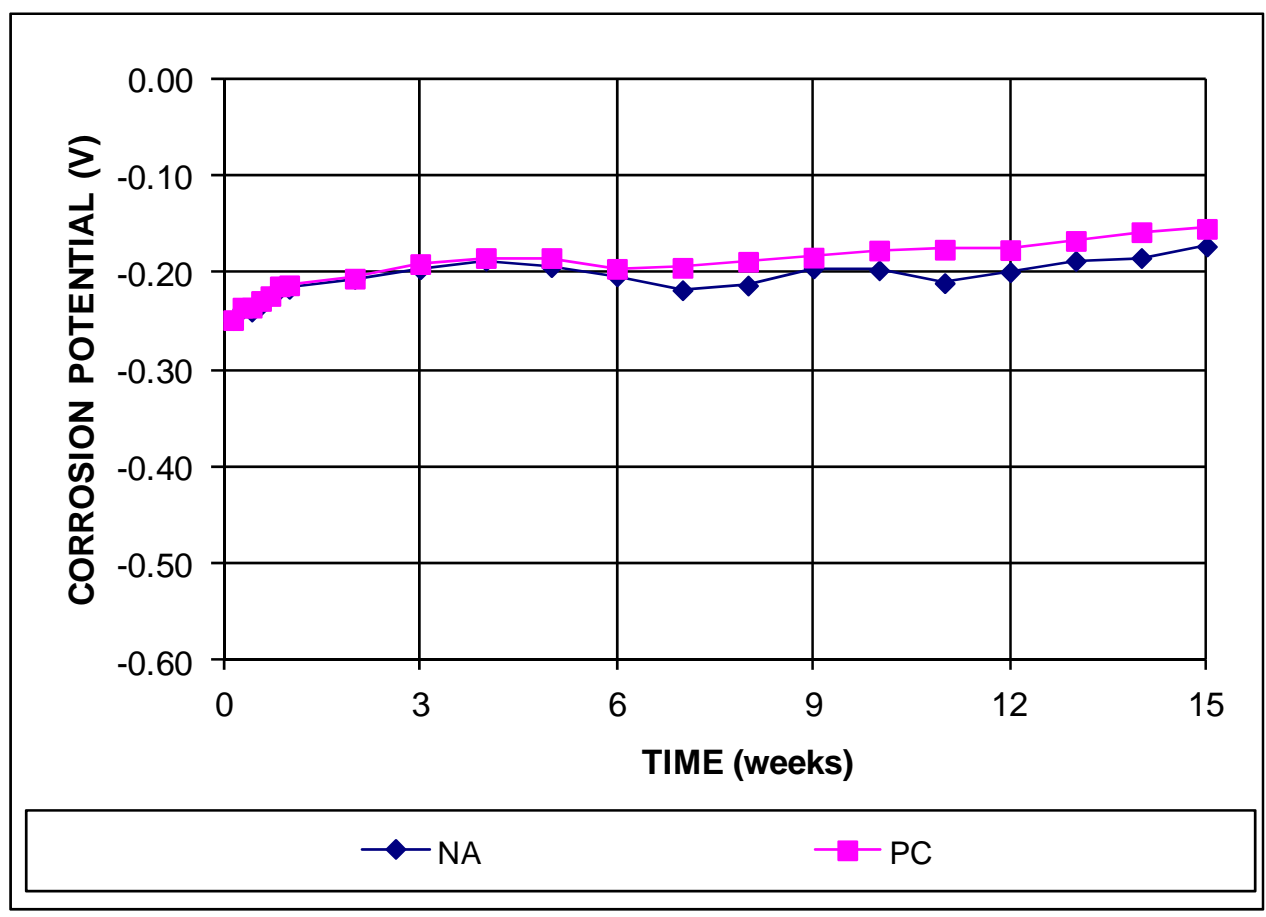

Figure 5d: Average corrosion potential (SCE) for bare prestressing strand in simulated NA and portland cement grout pore solutions. 


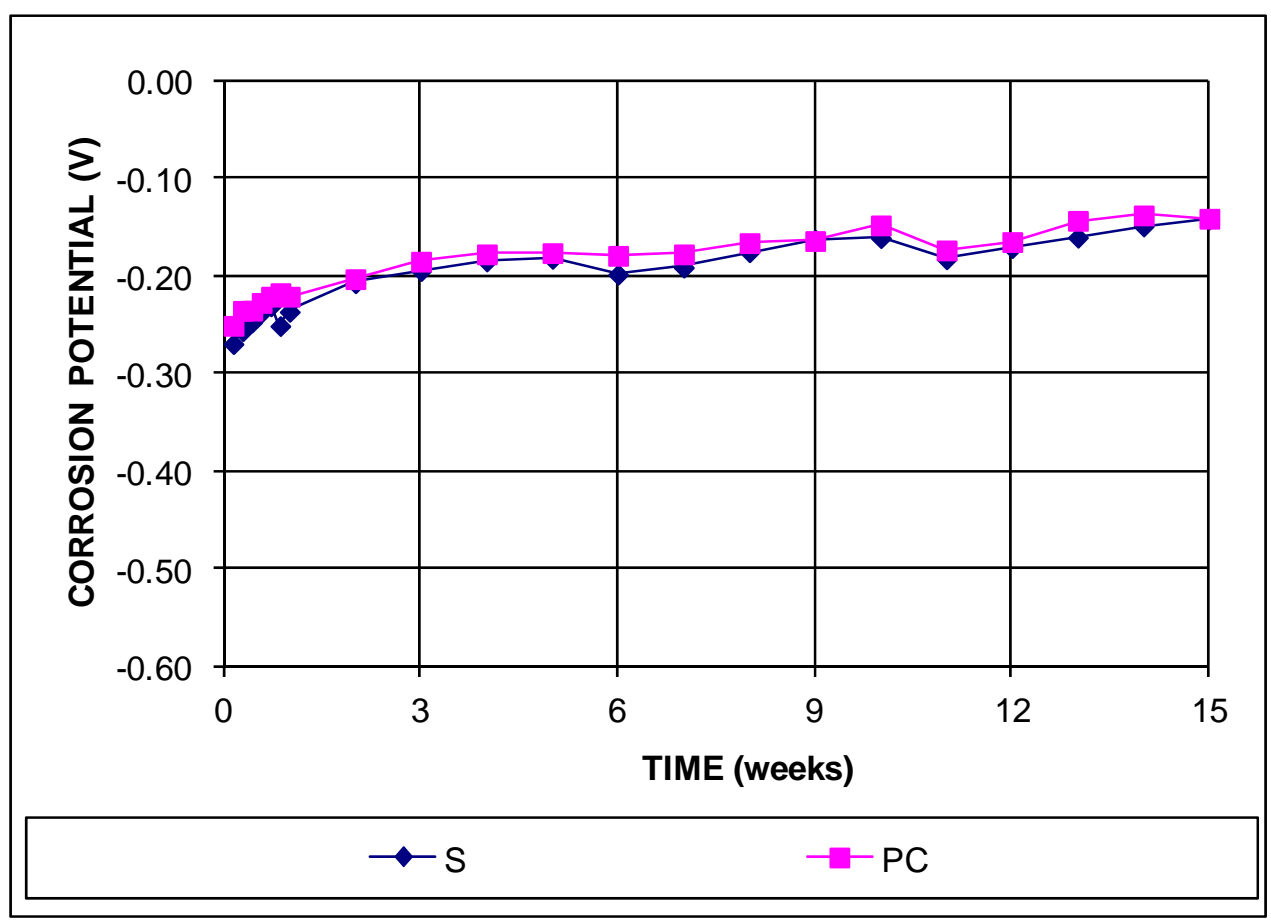

Figure 5e: Average corrosion potential (SCE) for bare prestressing strand in simulated Sika and portland cement grout pore solutions.

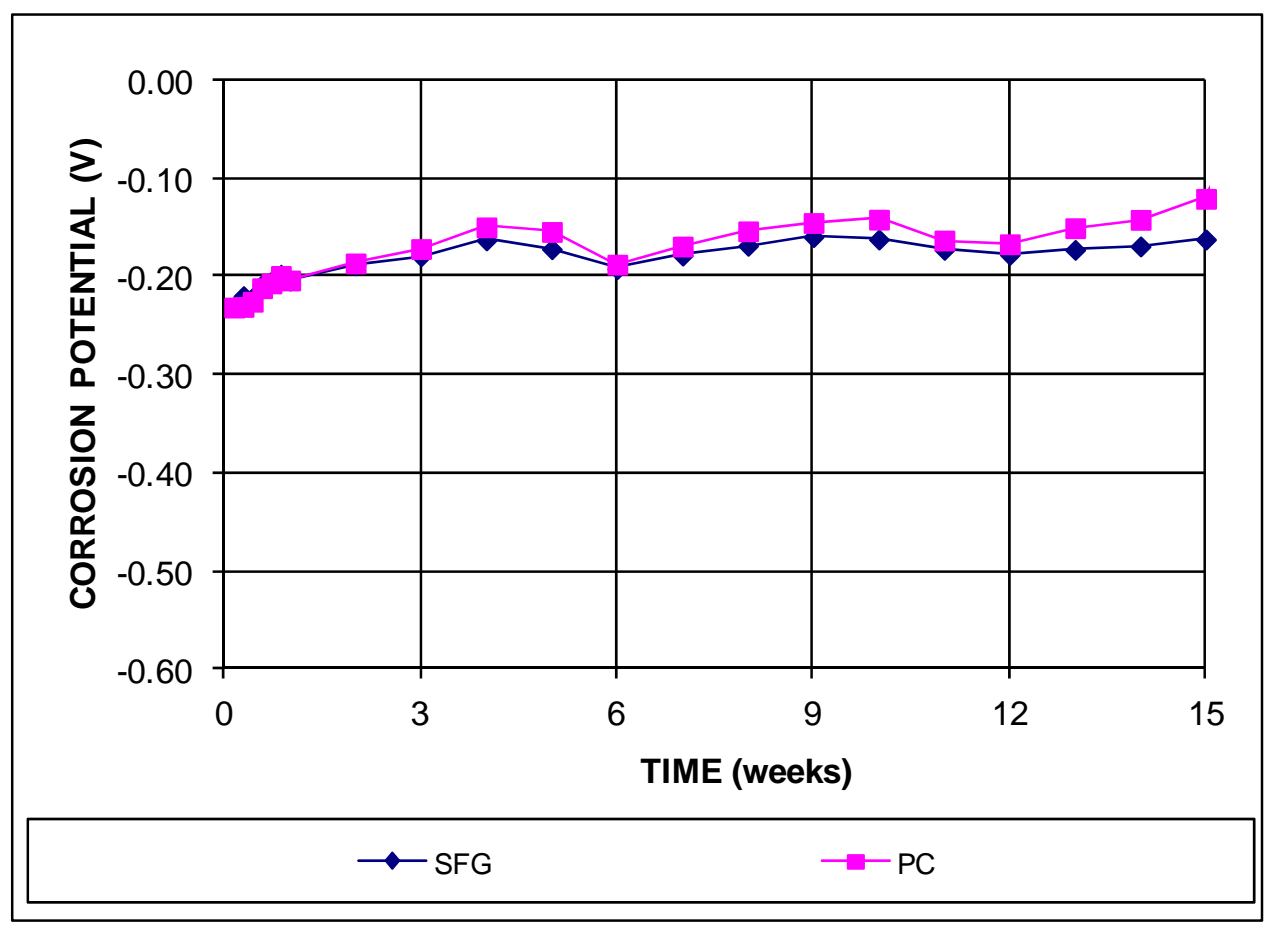

Figure 5f: Average corrosion potential (SCE) for bare prestressing strand in simulated Sika $\mathrm{w} /$ FerroGard and portland cement grout pore solutions. 
The corrosion losses at 15 weeks based on linear polarization resistance are shown in Table 9. As described earlier, linear polarization resistance (LPR) allows for the measurement of the total corrosion rate on a strand, including localized (microcell) corrosion between different regions on the same strand that is not reflected in the corrosion losses based on macrocell voltage drop (Table 4). Therefore, the losses reported by LPR are typically greater than the macrocell losses. LPR also allows corrosion losses to be determined on each strand individually.

As shown in Table 9, the strands in simulated gypsum grout exhibit high corrosion losses in both the G/SFG $(11.3 \mu \mathrm{m})$ and G/PC $(9.17 \mu \mathrm{m})$ systems. Of the systems without gypsum, the NA/PC specimens show slightly greater average corrosion losses than the other systems, with an average loss of $1.65 \mu \mathrm{m}$ for strands in the NA solution and $1.05 \mu \mathrm{m}$ for strands in the PC solution. All other strands show average corrosion losses based on LPR of less than $1 \mu \mathrm{m}$ at 15 weeks. The losses presented in Table 9 are supported by the corrosion potential readings for these specimens; the G/SFG and G/PC specimens exhibit high corrosion losses and have potentials more negative than $-0.25 \mathrm{~V}$, whereas the other specimens exhibiting lower corrosion losses have less negative potentials (around $-0.20 \mathrm{~V}$ ). 
Table 9: Total (LPR) Corrosion Losses $(\mu \mathrm{m})$ at 15 Weeks for Bare Prestressing Strand in Simulated Pore Solution

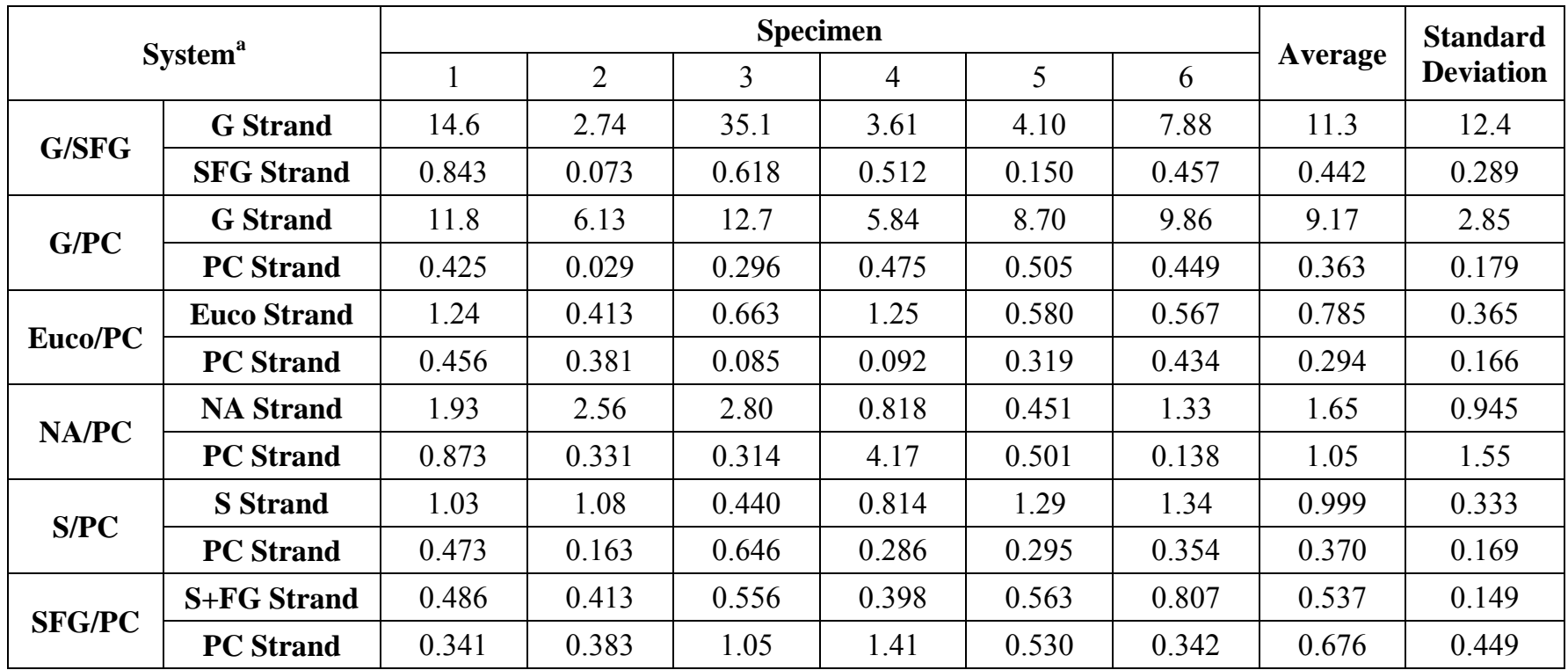

${ }^{\mathrm{a}} \mathrm{PC}=$ portland cement, $\mathrm{G}=$ gypsum, Euco = Euco Cable Grout, $\mathrm{S}=$ Sika, SFG = Sika w/FerroGard, NA = US Mix NA-50.

Figures 6a-6i show representative photos of the strands after testing. The strands in the gypsum grout in the G/SFG (Figures 6a and 6b) and G/PC (Figures 6c and 6d) tests show moderate corrosion products between the strands. All other strands appear clean after testing, as demonstrated in Figure 6i.

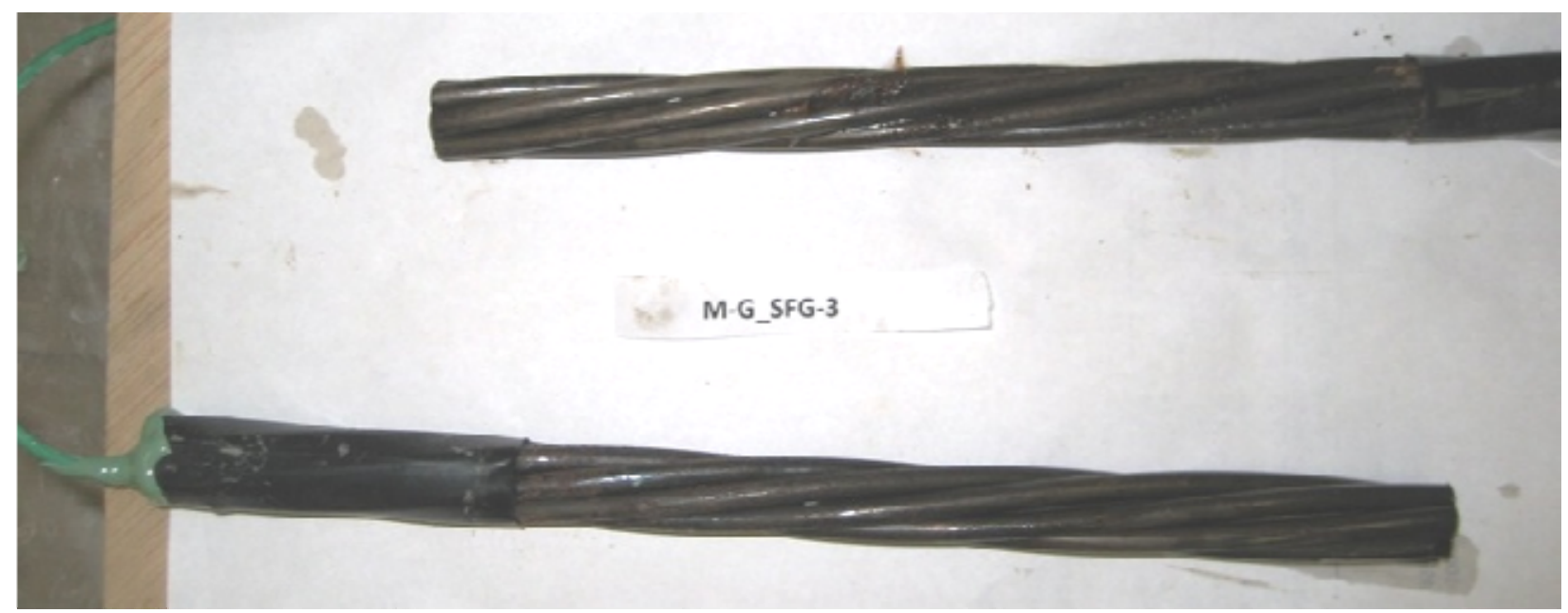

Figure 6a: Specimen G/SFG-3, 15 weeks. Strand in simulated gypsum pore solution (top) and simulated Sika w/FerroGard pore solution (bottom). 


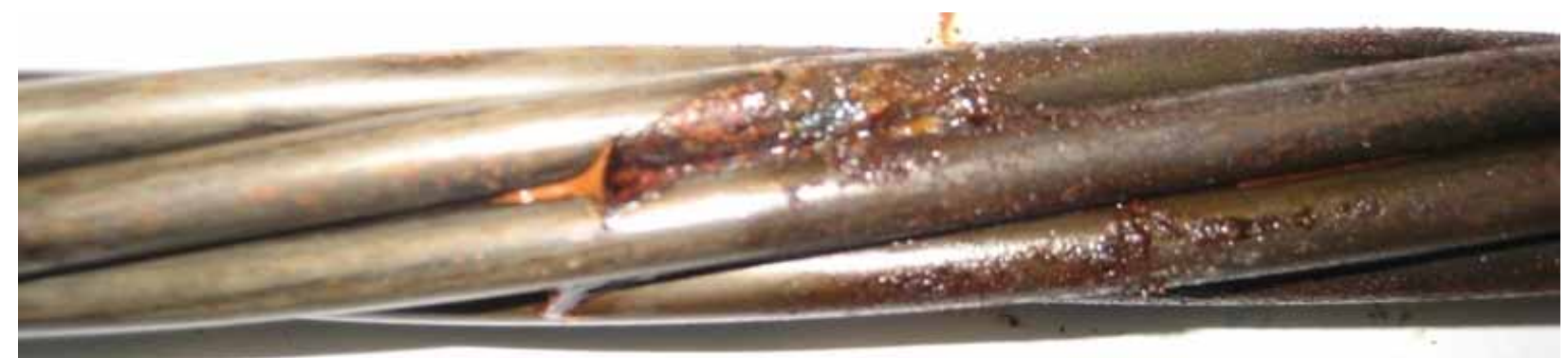

Figure 6b: Close-up of strand in simulated gypsum grout pore solution, specimen G/SFG-3.

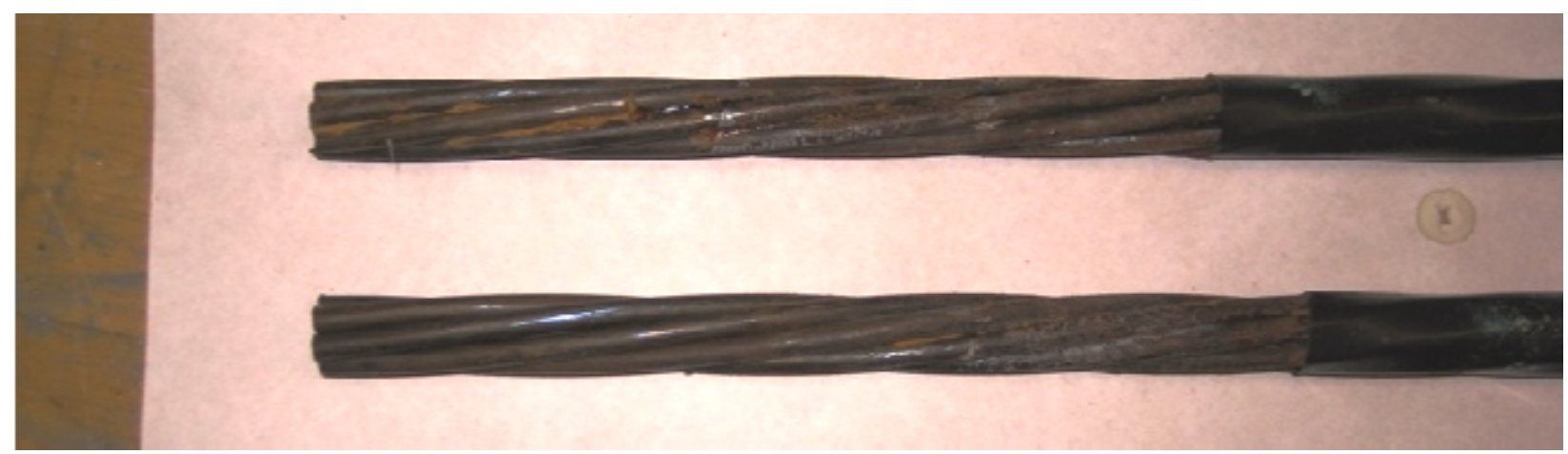

Figure 6c: Specimen G/PC-1, 15 weeks. Strand in simulated gypsum grout pore solution (top) and simulated portland cement grout pore solution (bottom).

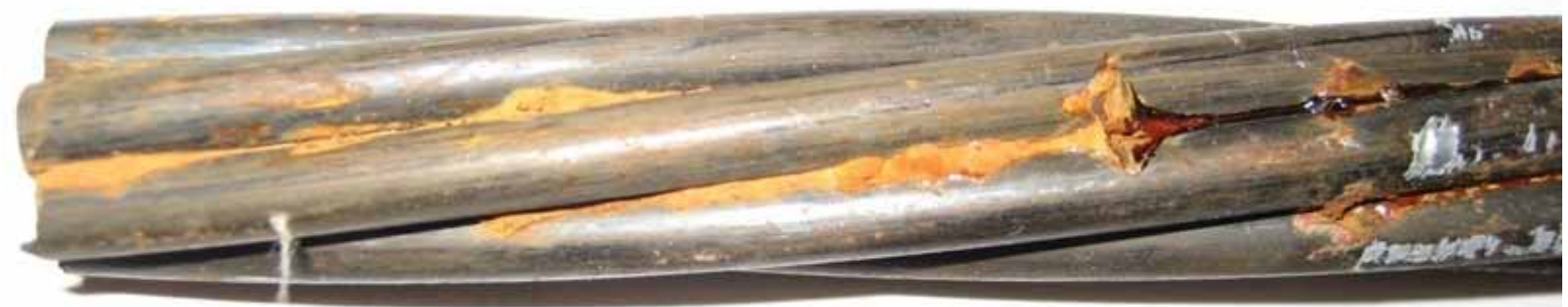

Figure 6d: Close-up of strand in simulated gypsum grout pore solution, specimen G/PC-1. 


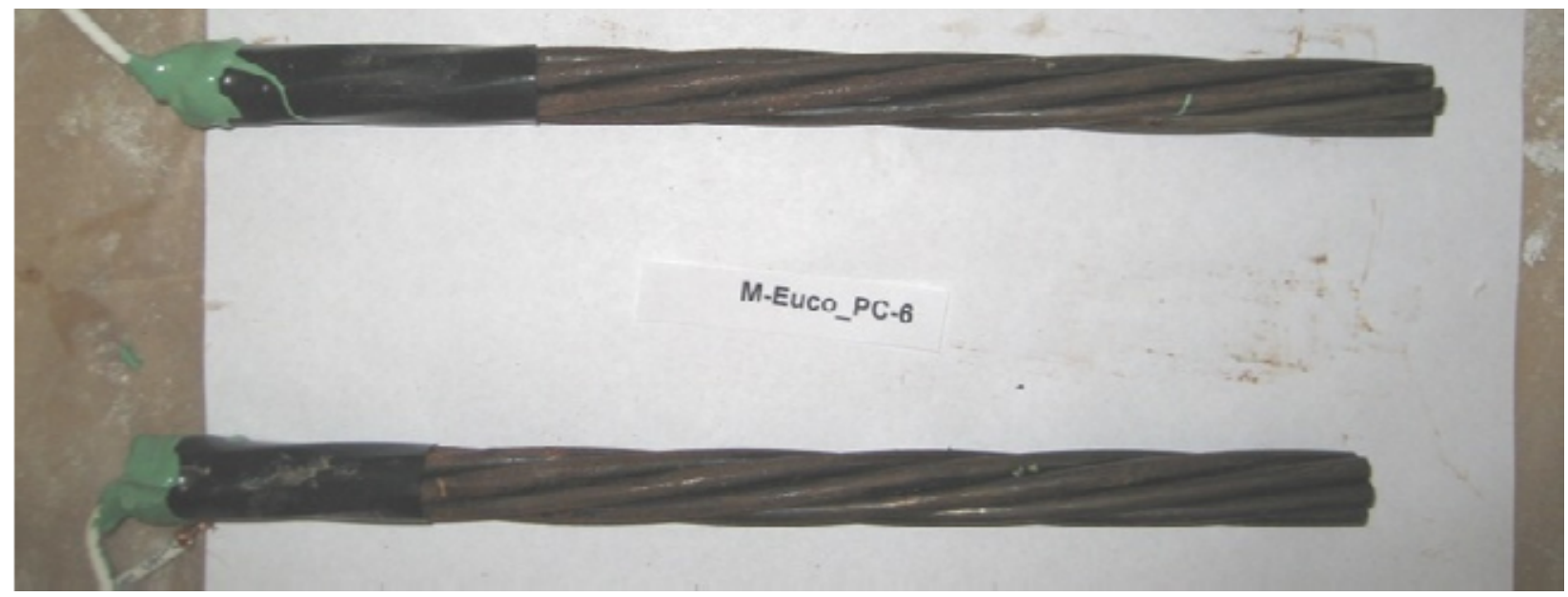

Figure 6e: Specimen Euco/PC-6, 15 weeks. Strand in simulated Euco grout pore solution (top) and simulated portland cement grout pore solution (bottom).

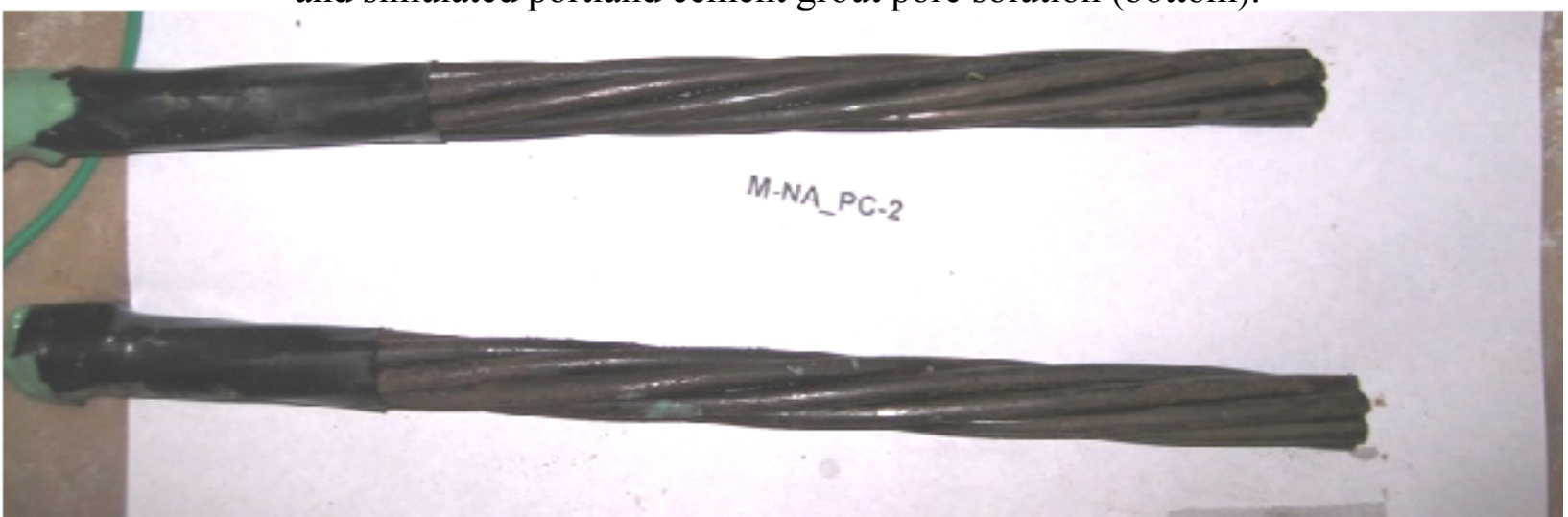

Figure 6f: Specimen NA/PC-2, 15 weeks. Strand in simulated NA grout pore solution (top) and simulated portland cement grout pore solution (bottom).

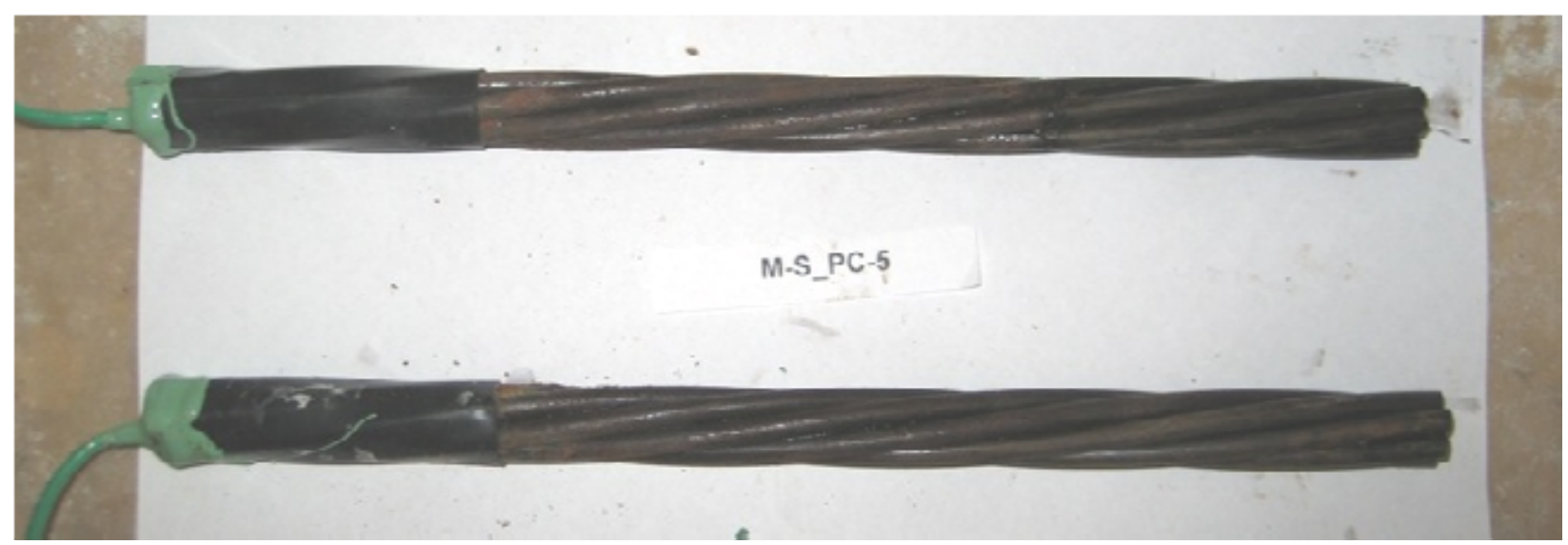

Figure 6g: Specimen S/PC-5, 15 weeks. Strand in simulated Sika grout pore solution (top) and simulated portland cement grout pore solution (bottom). 


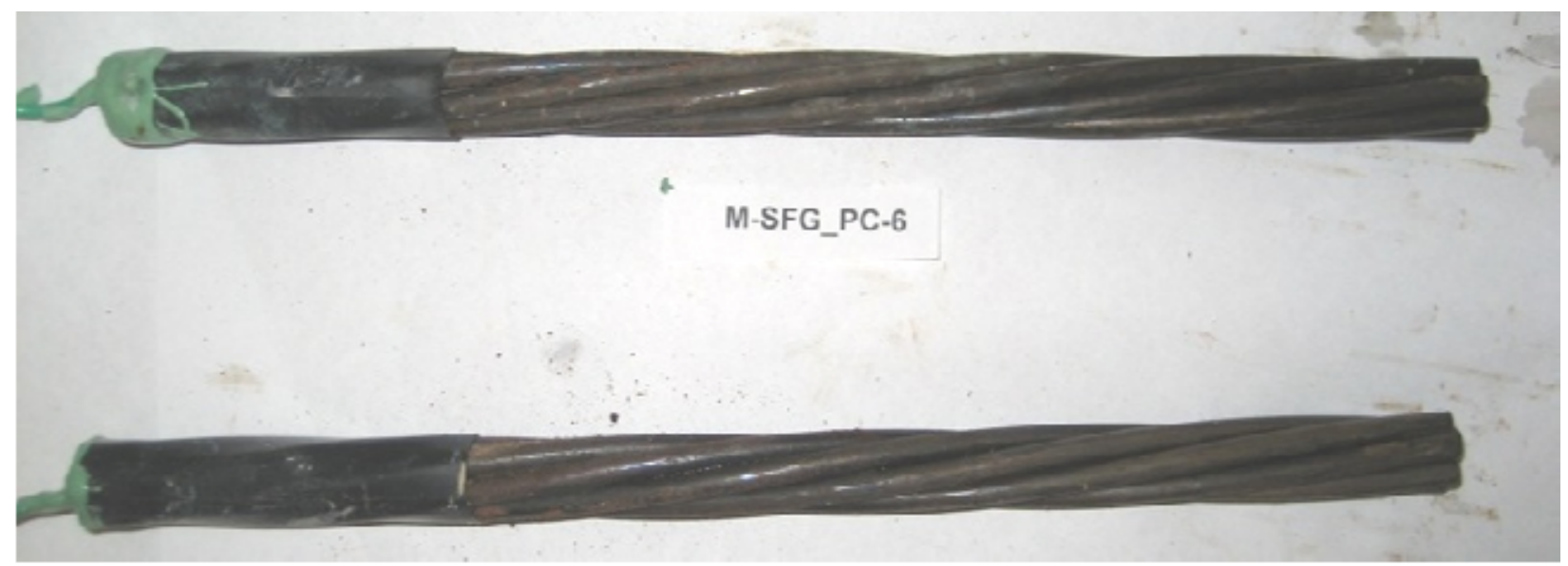

Figure 6h: Specimen SFG/PC-6, 15 weeks. Strand in simulated Sika w/FerroGard grout pore solution (top) and simulated portland cement grout pore solution (bottom).

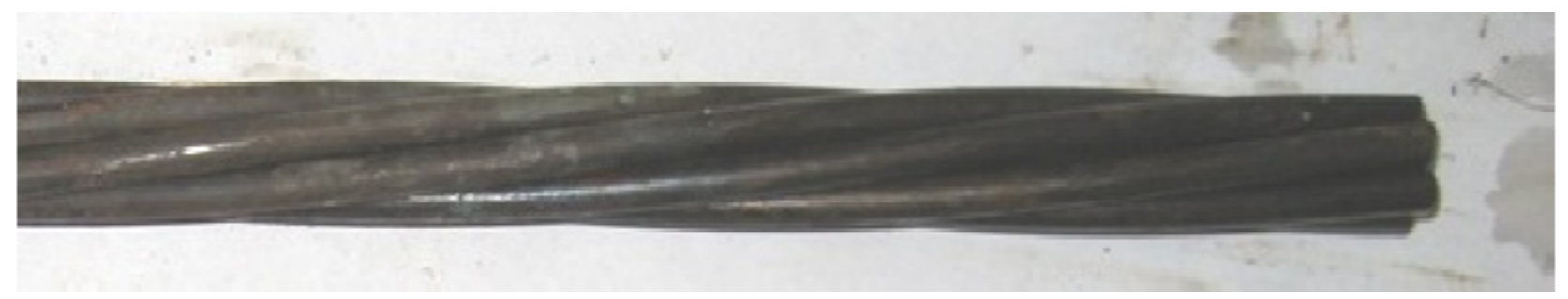

Figure 6i: Specimen SFG/PC-6, 15 weeks. Strand in simulated Sika w/FerroGard grout pore solution showing no significant corrosion products.

\section{Grout-Wrapped Strand}

The average macrocell corrosion rates for the grout-wrapped prestressing strands are shown in Figure 7; corrosion losses at 15 and 30 weeks are listed in Tables 10a and 10b, respectively. Grout-wrapped specimens containing gypsum and Sika w/FerroGard grout (G/SFGGW) have a corrosion rate as high as $11.7 \mu \mathrm{m} / \mathrm{yr}$ during the first week of testing (Figure 7a). By the end of the first week, the corrosion rate drops to about $7 \mu \mathrm{m} / \mathrm{yr}$. The corrosion rate remains between 5.7 and $8.6 \mu \mathrm{m} / \mathrm{yr}$ for the remainder of the test, similar to but slightly higher than the rate observed in the bare-strand G/SFG specimens (Figure 4a). The other grout-wrapped specimens, S/PC-GW and SFG/PC-GW, show average macrocell corrosion rates of less than 0.5 
$\mu \mathrm{m} / \mathrm{yr}$ throughout the test (Figure $7 \mathrm{~b}$ ), which is similar to the behavior of the corresponding barestrand specimens.

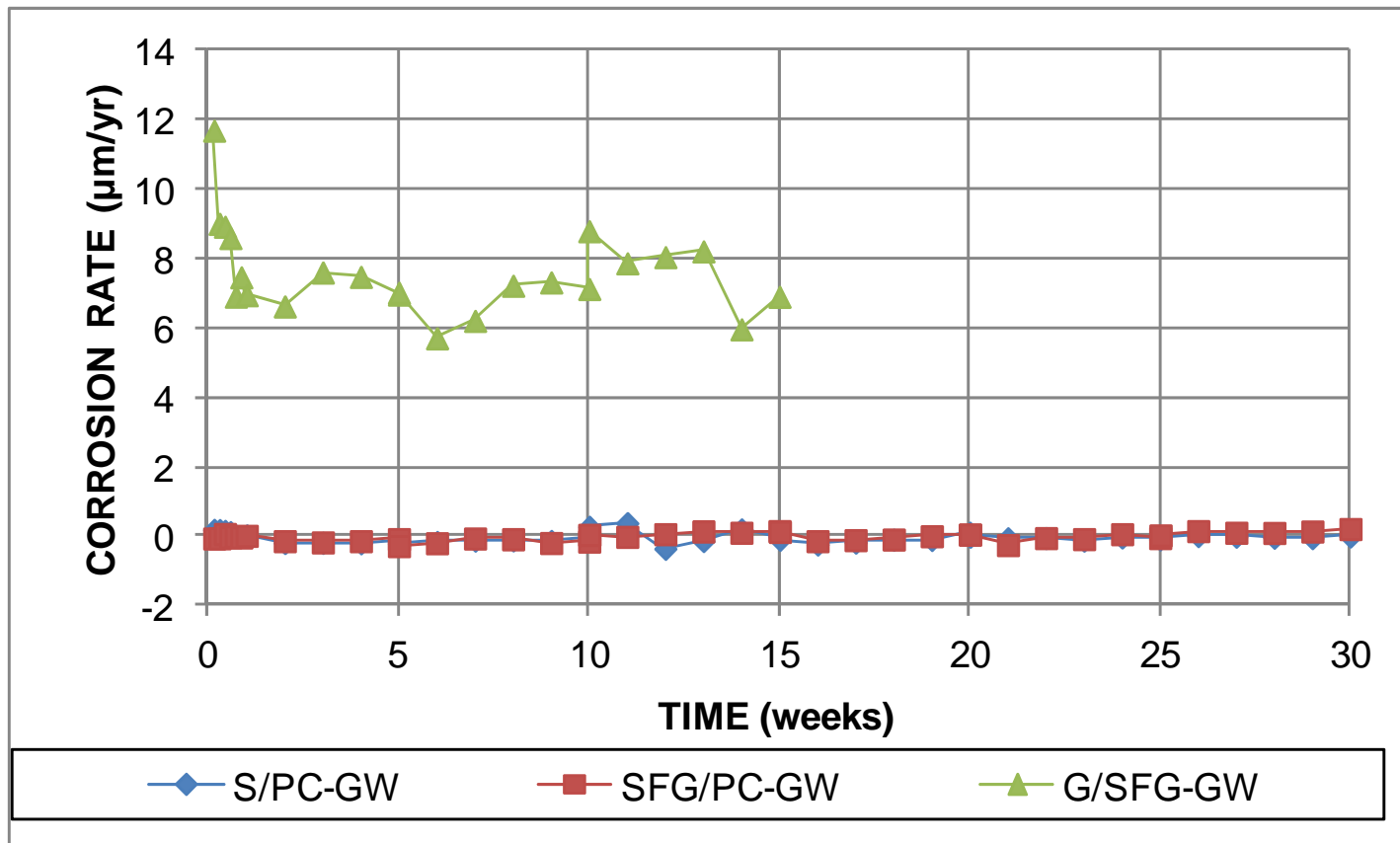

Figure 7a: Average macrocell corrosion rates for grout-wrapped (GW) strand.

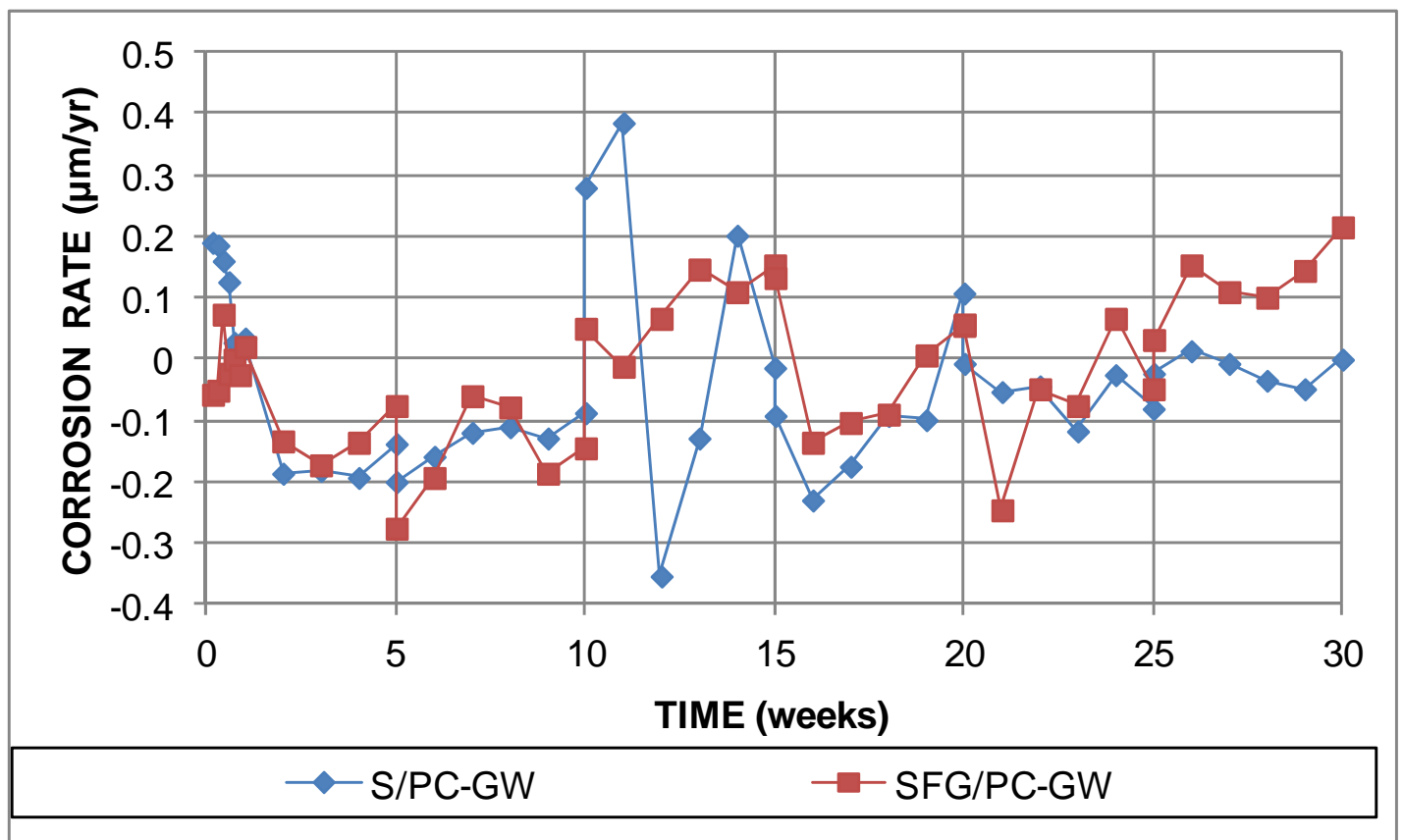

Figure 7b: Average macrocell corrosion rates for grout-wrapped (GW) strand (Different scale). 
Table 10a: Macrocell Corrosion Losses $(\mu \mathrm{m})$ at 15 Weeks for Grout-Wrapped Prestressing Strand

\begin{tabular}{|c|c|c|c|c|c|c|c|c|}
\hline \multirow{2}{*}{ System $^{\mathrm{a}}$} & \multicolumn{6}{|c|}{ Specimen } & \multirow{2}{*}{ Average } & \multirow{2}{*}{$\begin{array}{l}\text { Standard } \\
\text { Deviation }\end{array}$} \\
\hline & 1 & 2 & 3 & 4 & 5 & 6 & & \\
\hline G/SFG-GW & 2.43 & 1.90 & 3.14 & 1.34 & 1.54 & 2.04 & 2.07 & 0.652 \\
\hline S/PC-GW & -0.063 & 0.014 & -0.029 & 0.054 & -0.026 & -0.078 & -0.021 & 0.049 \\
\hline SFG/PC-GW & 0.005 & 0.019 & -0.122 & -0.043 & -0.026 & 0.084 & -0.014 & 0.069 \\
\hline
\end{tabular}

${ }^{\mathbf{a}} \mathrm{PC}=$ portland cement, $\mathrm{G}=$ gypsum, $\mathrm{S}=$ Sika, $\mathrm{SFG}=$ Sika w/FerroGard

Table 10b: Macrocell Corrosion Losses $(\mu \mathrm{m})$ at 30 Weeks for Grout-Wrapped Prestressing Strand

\begin{tabular}{|c|c|c|c|c|c|c|c|c|}
\hline \multirow{2}{*}{ System $^{a}$} & \multicolumn{6}{|c|}{ Specimen } & \multirow{2}{*}{ Average } & \multirow{2}{*}{$\begin{array}{l}\text { Standard } \\
\text { Deviation }\end{array}$} \\
\hline & 1 & 2 & 3 & 4 & 5 & 6 & & \\
\hline S/PC-GW & -0.057 & 0.010 & -0.034 & 0.056 & -0.031 & -0.173 & -0.038 & 0.077 \\
\hline SFG/PC-GW & 0.007 & 0.062 & -0.249 & -0.082 & -0.030 & 0.222 & -0.012 & 0.156 \\
\hline
\end{tabular}

${ }^{\mathbf{a}} \mathrm{PC}=$ portland cement, $\mathrm{S}=\mathrm{Sika}, \mathrm{SFG}=$ SikaGrout $300 \mathrm{PT}$ with FerroGard

After 15 weeks, the G/SFG-GW specimens have the greatest average macrocell corrosion loss, $2.07 \mu \mathrm{m}$ (Table 10a). The average losses for the S/PC-GW and SFG/PC-GW specimens remain below $0.1 \mu \mathrm{m}$ at both 15 weeks (Table 10a) and 30 weeks (Table 10b).

Figures $8 \mathrm{a}-8 \mathrm{c}$ show the average corrosion potentials for the grout-wrapped strands. For the G/SFG-GW (Figure 8a) specimens, the potential of the strands in the gypsum grout is significantly more negative (between -0.50 and $-0.60 \mathrm{~V}$ ) than the potential of the strand in the Sika w/FerroGard grout (between -0.20 and $-0.30 \mathrm{~V}$ ), suggesting active corrosion on the strand in the gypsum grout. The other systems (Figures $8 \mathrm{~b}$ and $8 \mathrm{c}$ ) show potentials between -0.12 and $-0.22 \mathrm{~V}$ with negligible differences in potential between the two grouts in each combination. The average corrosion potential of the strand in the Sika w/FerroGard grout is more negative when coupled with the strand in the gypsum grout (Figure 8a) than when coupled with the strand in the portland cement grout (Figure 8c). 


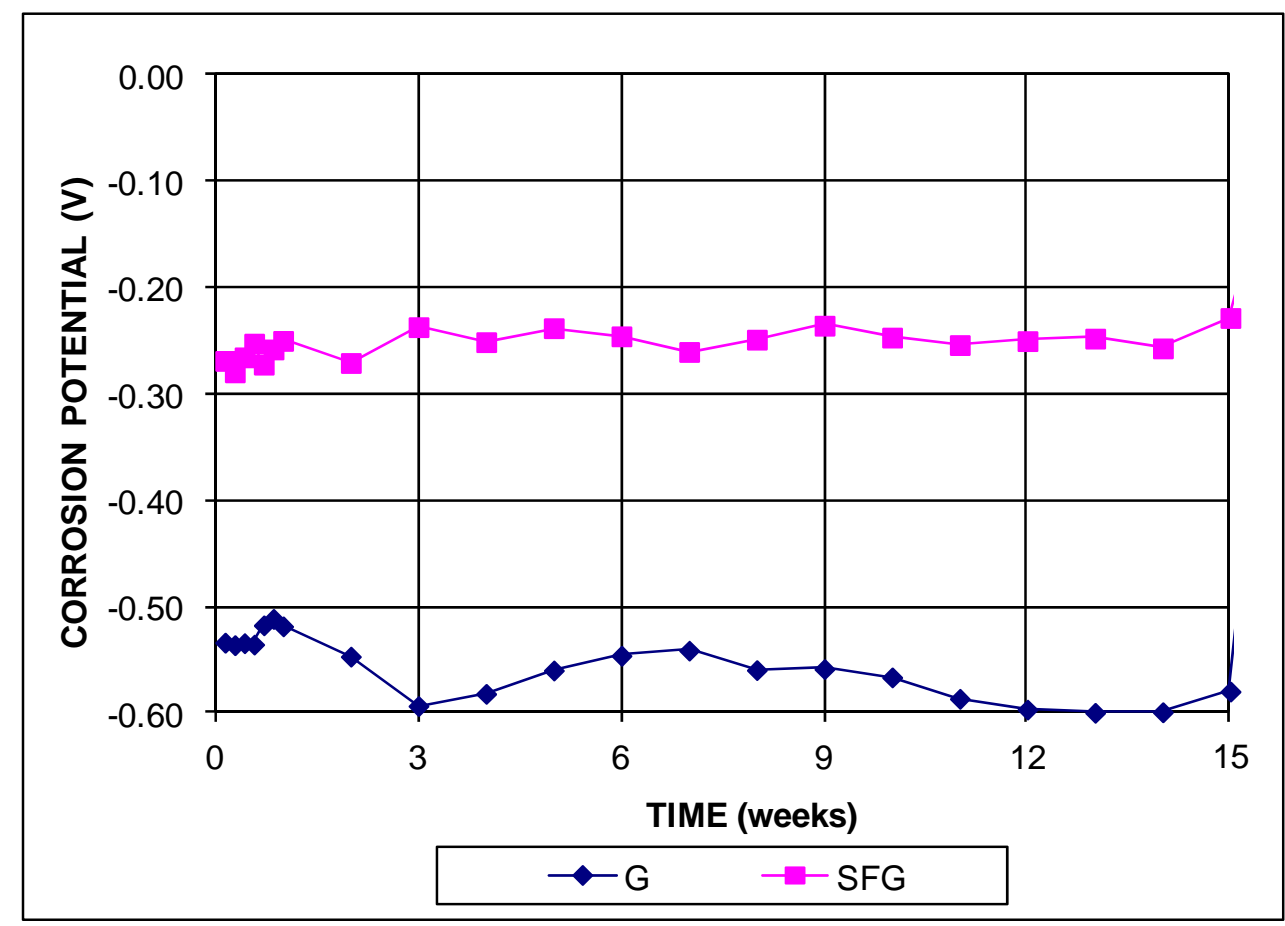

Figure 8a: Average corrosion potential (SCE) for grout-wrapped prestressing strand in gypsum and Sika w/FerroGard grouts.

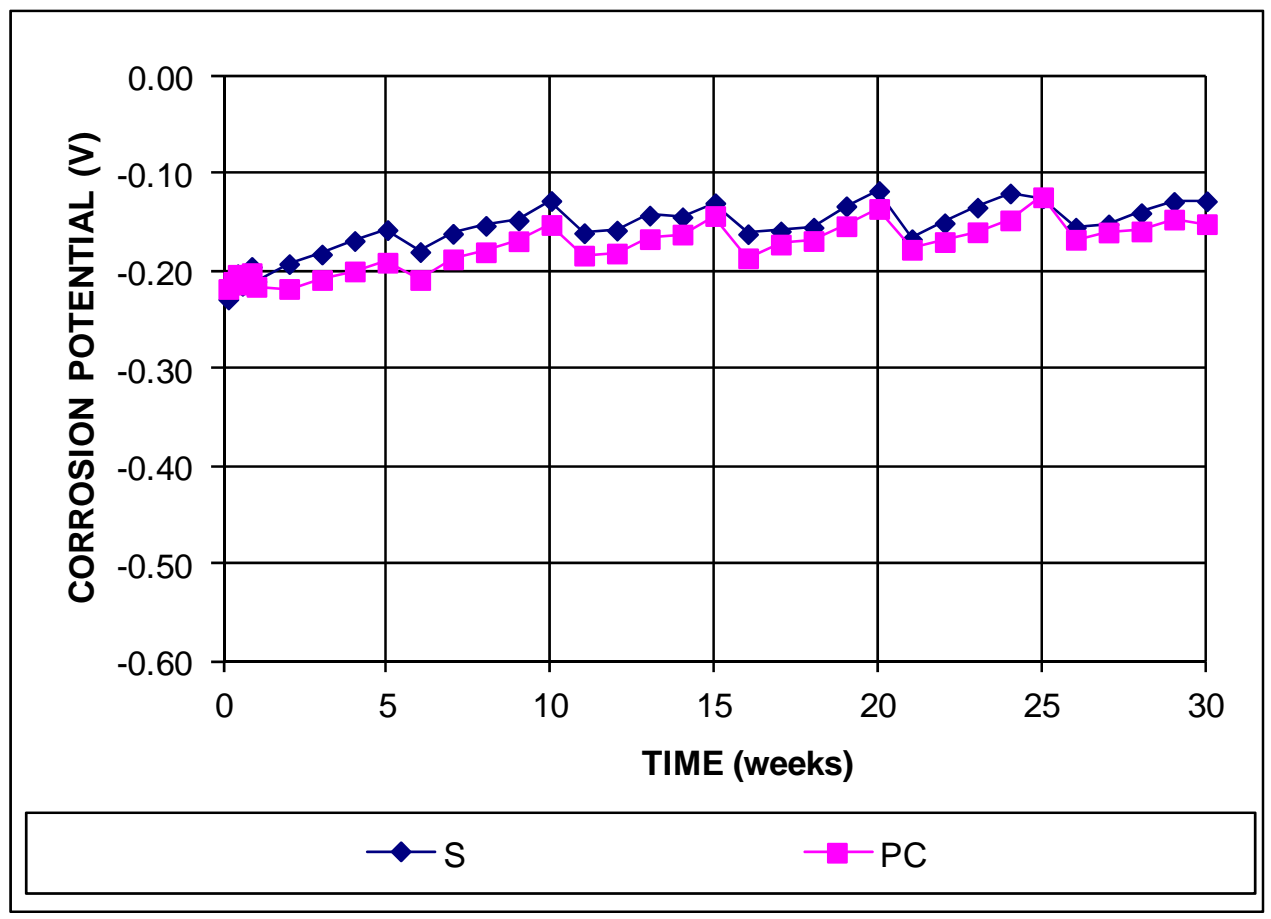

Figure 8b: Average corrosion potential (SCE) for grout-wrapped prestressing strand in Sika and portland cement grouts. 


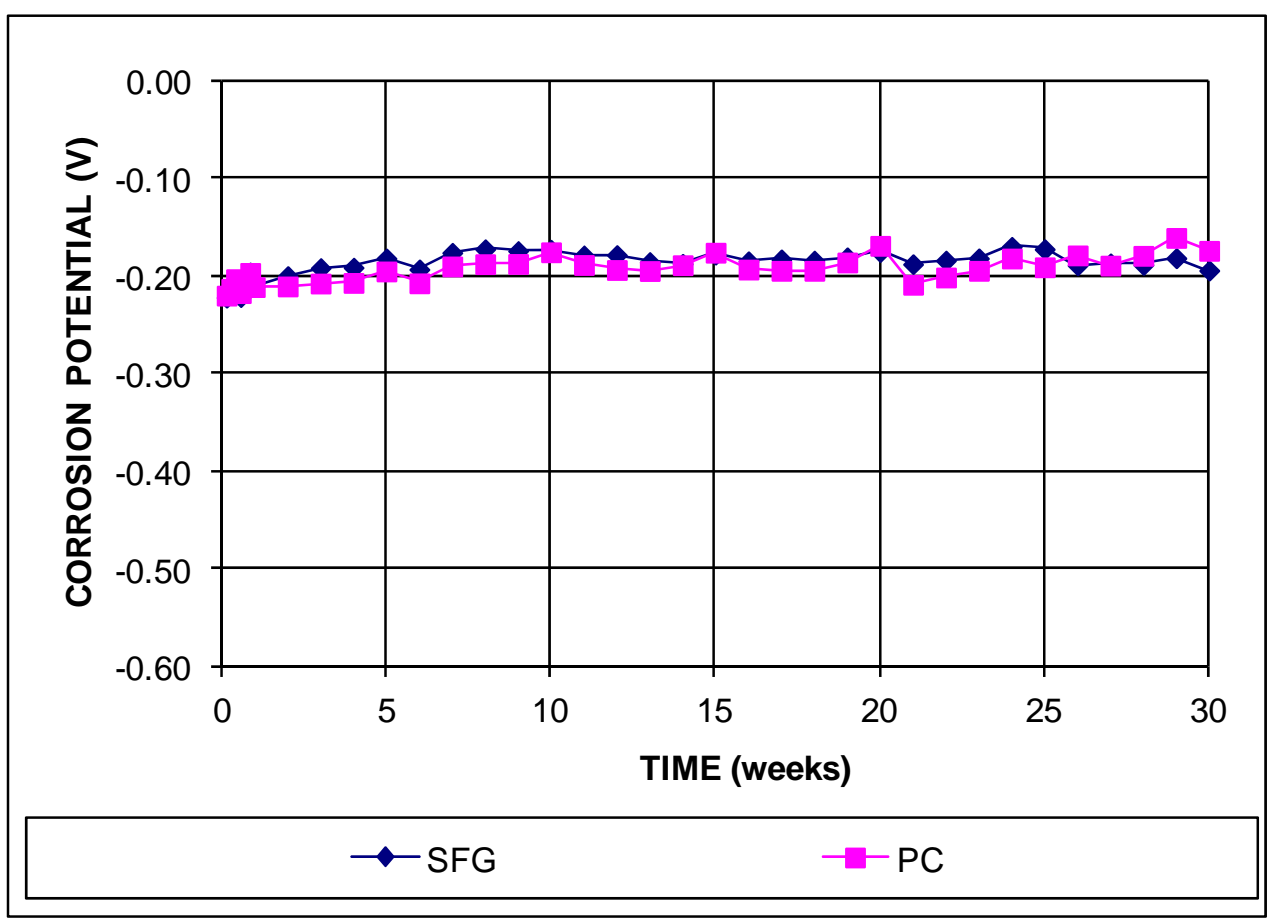

Figure 8c: Average corrosion potential (SCE) for grout-wrapped prestressing strand in Sika $\mathrm{w} /$ FerroGard and portland cement grouts.

The corrosion losses at 15 and 30 weeks based on LPR are shown in Tables 11a and 11b, respectively. At 15 weeks, the strands in gypsum grout show high corrosion losses, $7.60 \mu \mathrm{m}$. All other strands show average corrosion losses based on LPR of less than $1 \mu \mathrm{m}$ at 15 weeks. At 30 weeks (Table 11b), strands in Sika w/FerroGard grout show losses of $2.63 \mu \mathrm{m}$, followed by strands in Sika grout at $1.93 \mu \mathrm{m}$. The strands in portland cement grout exhibit slightly lower losses, 1.40 and $1.85 \mu \mathrm{m}$, for S/PC-GW and SFG/PC-GW, respectively. 
Table 11a: Total (LPR) Corrosion Losses $(\mu \mathrm{m})$ at 15 Weeks for Grout-Wrapped Prestressing Strand

\begin{tabular}{|c|c|c|c|c|c|c|c|c|c|}
\hline \multirow{2}{*}{\multicolumn{2}{|c|}{ System $^{\mathrm{a}}$}} & \multicolumn{6}{|c|}{ Specimen } & \multirow{3}{*}{$\begin{array}{c}\text { Average } \\
7.60\end{array}$} & \multirow{3}{*}{$\begin{array}{c}\begin{array}{c}\text { Standard } \\
\text { Deviation }\end{array} \\
2.06\end{array}$} \\
\hline & & \multirow{2}{*}{$\begin{array}{c}1 \\
5.70\end{array}$} & \multirow{2}{*}{$\begin{array}{c}2 \\
8.86\end{array}$} & \multirow{2}{*}{$\begin{array}{c}3 \\
7.27\end{array}$} & \multirow{2}{*}{$\begin{array}{c}4 \\
6.76\end{array}$} & \multirow{2}{*}{$\begin{array}{c}5 \\
11.1\end{array}$} & \multirow{2}{*}{$\begin{array}{c}6 \\
5.90\end{array}$} & & \\
\hline & G Strand & & & & & & & & \\
\hline GW & $\begin{array}{c}\text { SFG } \\
\text { Strand }\end{array}$ & 0.292 & 0.234 & 0.237 & 0.318 & 0.044 & 0.298 & 0.237 & 0.101 \\
\hline \multirow{2}{*}{$\begin{array}{c}\text { S/PC- } \\
\text { GW }\end{array}$} & S Strand & 0.733 & 0.855 & 0.690 & 0.806 & 1.07 & 1.12 & 0.878 & 0.177 \\
\hline & PC Strand & 0.395 & 0.399 & 0.327 & 0.413 & 0.468 & 0.373 & 0.396 & 0.046 \\
\hline \multirow{2}{*}{$\begin{array}{c}\text { SFG/PC- } \\
\text { GW }\end{array}$} & $\begin{array}{c}\text { SFG } \\
\text { Strand }\end{array}$ & 0.736 & 0.731 & 0.908 & 0.947 & 0.358 & 0.989 & 0.778 & 0.232 \\
\hline & PC Strand & 0.450 & 0.728 & 0.308 & 0.442 & 0.298 & 0.509 & 0.456 & 0.157 \\
\hline
\end{tabular}

${ }^{\mathbf{a}} \mathrm{PC}=$ portland cement, $\mathrm{G}=$ gypsum, $\mathrm{S}=$ Sika, $\mathrm{SFG}=$ Sika w/FerroGard.

Table 11b: Total (LPR) Corrosion Losses $(\mu \mathrm{m})$ at 30 Weeks for Grout-Wrapped Prestressing Strand

\begin{tabular}{|c|c|c|c|c|c|c|c|c|c|}
\hline \multirow{2}{*}{\multicolumn{2}{|c|}{ System $^{a}$}} & \multicolumn{6}{|c|}{ Specimen } & \multirow{3}{*}{$\begin{array}{c}\text { Average } \\
1.93\end{array}$} & \multirow{3}{*}{$\begin{array}{c}\text { Standard } \\
\text { Deviation }\end{array}$} \\
\hline & & \multirow{2}{*}{$\begin{array}{c}1 \\
1.60\end{array}$} & \multirow{2}{*}{$\begin{array}{c}2 \\
1.80\end{array}$} & \multirow{2}{*}{$\begin{array}{c}3 \\
1.70\end{array}$} & \multirow{2}{*}{$\begin{array}{c}4 \\
1.81\end{array}$} & \multirow{2}{*}{$\begin{array}{c}5 \\
2.01\end{array}$} & \multirow{2}{*}{$\begin{array}{c}6 \\
2.68\end{array}$} & & \\
\hline S/PC- & S Strand & & & & & & & & \\
\hline GW & PC Strand & 1.27 & 1.26 & 1.40 & 1.48 & 1.30 & 1.67 & 1.40 & 0.156 \\
\hline \multirow{2}{*}{$\begin{array}{c}\text { SFG/PC- } \\
\text { GW }\end{array}$} & $\begin{array}{c}\text { SFG } \\
\text { Strand }\end{array}$ & 3.90 & 2.19 & 2.22 & 3.63 & 1.43 & 2.38 & 2.63 & 0.948 \\
\hline & PC Strand & 1.83 & 1.73 & 1.32 & 1.43 & 2.90 & 1.88 & 1.85 & 0.562 \\
\hline
\end{tabular}

${ }^{\mathbf{a}} \mathrm{PC}=$ portland cement, $\mathrm{G}=$ gypsum, $\mathrm{S}=$ Sika, $\mathrm{SFG}=$ Sika w/FerroGard.

Figures 9a-9i show representative photographs of the grout-wrapped specimens after testing, both before and after removal of the grout. Before removal of the grout, all specimens show staining on the grout up to the waterline (Figures 9a, 9e, 9g). This staining is not due to corrosion, but rather due to contact between the grout and the pore solution. The stains do not penetrate the surface of the grout, as shown in Figure 9i. The strands in gypsum grout show staining and cracking of the grout at several locations (Figures 9a, 9b); removal of the grout shows heavy corrosion at these locations (Figures 9c, 9d). Some specimens exhibited cracking due to shrinkage of the grout-wrapped specimens (Figure 9g); this did not result in corrosion on the strands (Figure 9h). The other strands show no signs of corrosion (Figures 9c, 9f, 9h). 


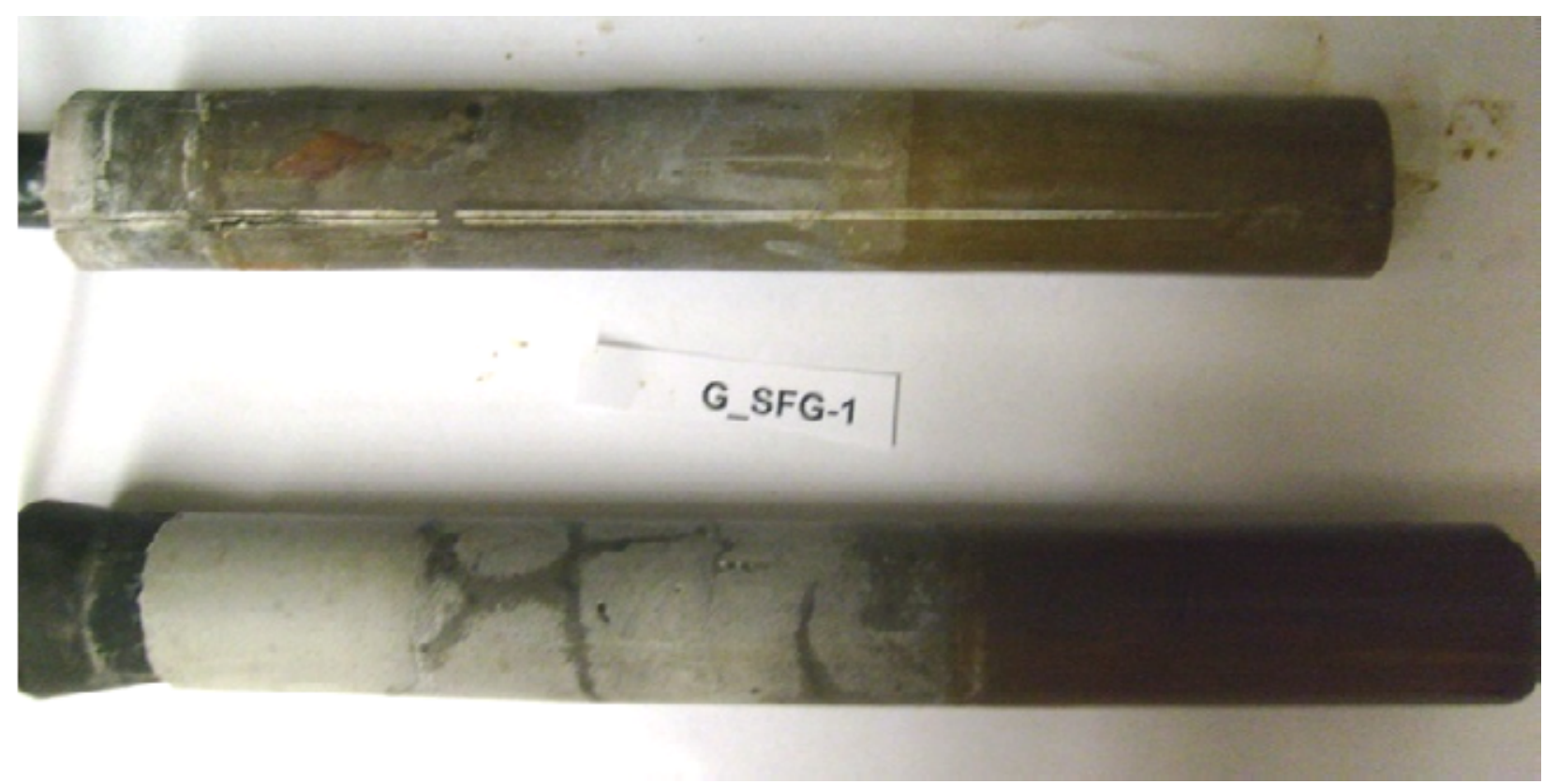

Figure 9a: Specimen G/SFG-1, 15 weeks. Strand in gypsum grout (top) and Sika w/FerroGard grout (bottom).

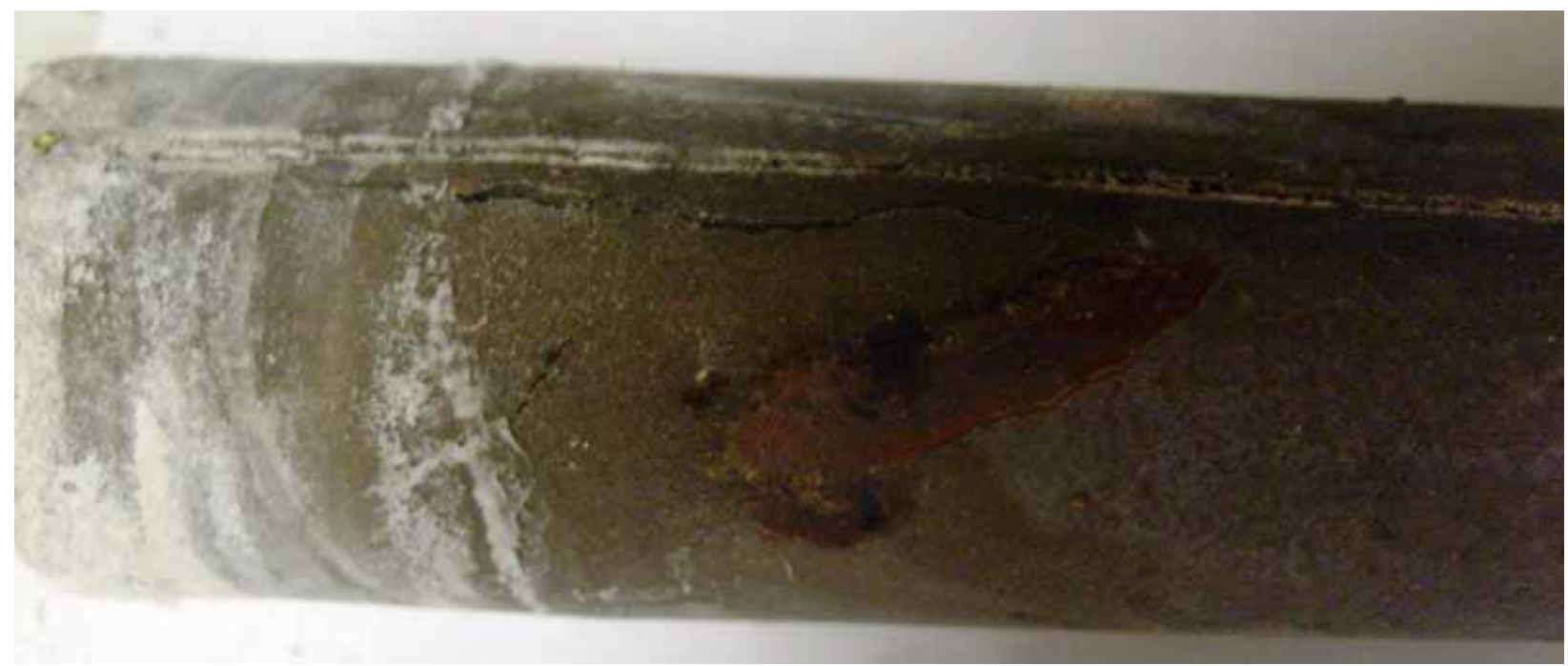

Figure 9b: Specimen G/SFG-2, 15 weeks. Close-up on strand in gypsum grout. 


\section{G_SFG-1}

Figure 9c: Specimen G/SFG-1, 15 weeks, after removal of grout. Strand in gypsum grout (top) and Sika w/FerroGard grout (bottom).

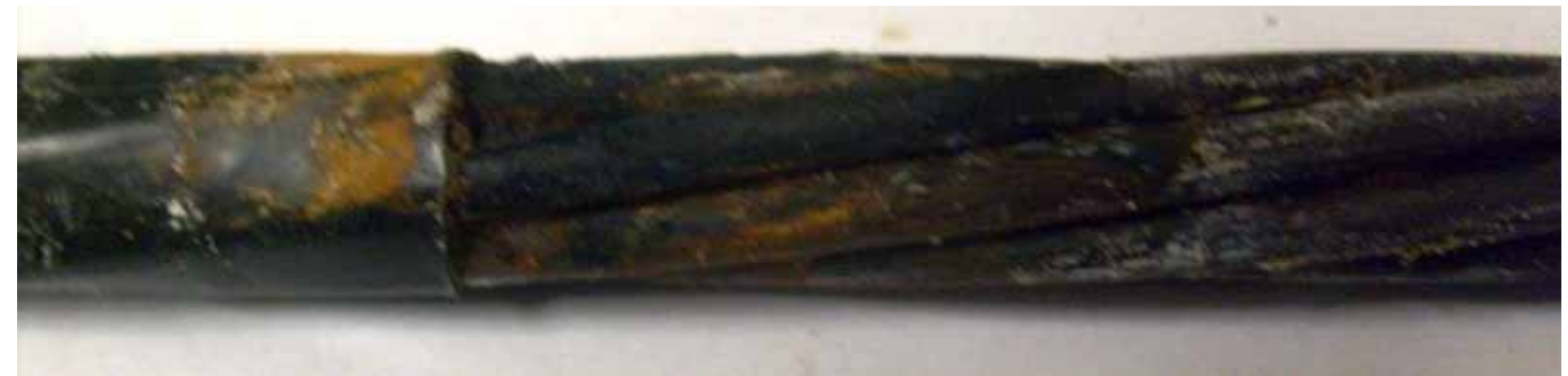

Figure 9d: Specimen G/SFG-1, 15 weeks, after removal of grout. Close-up on strand in gypsum grout.

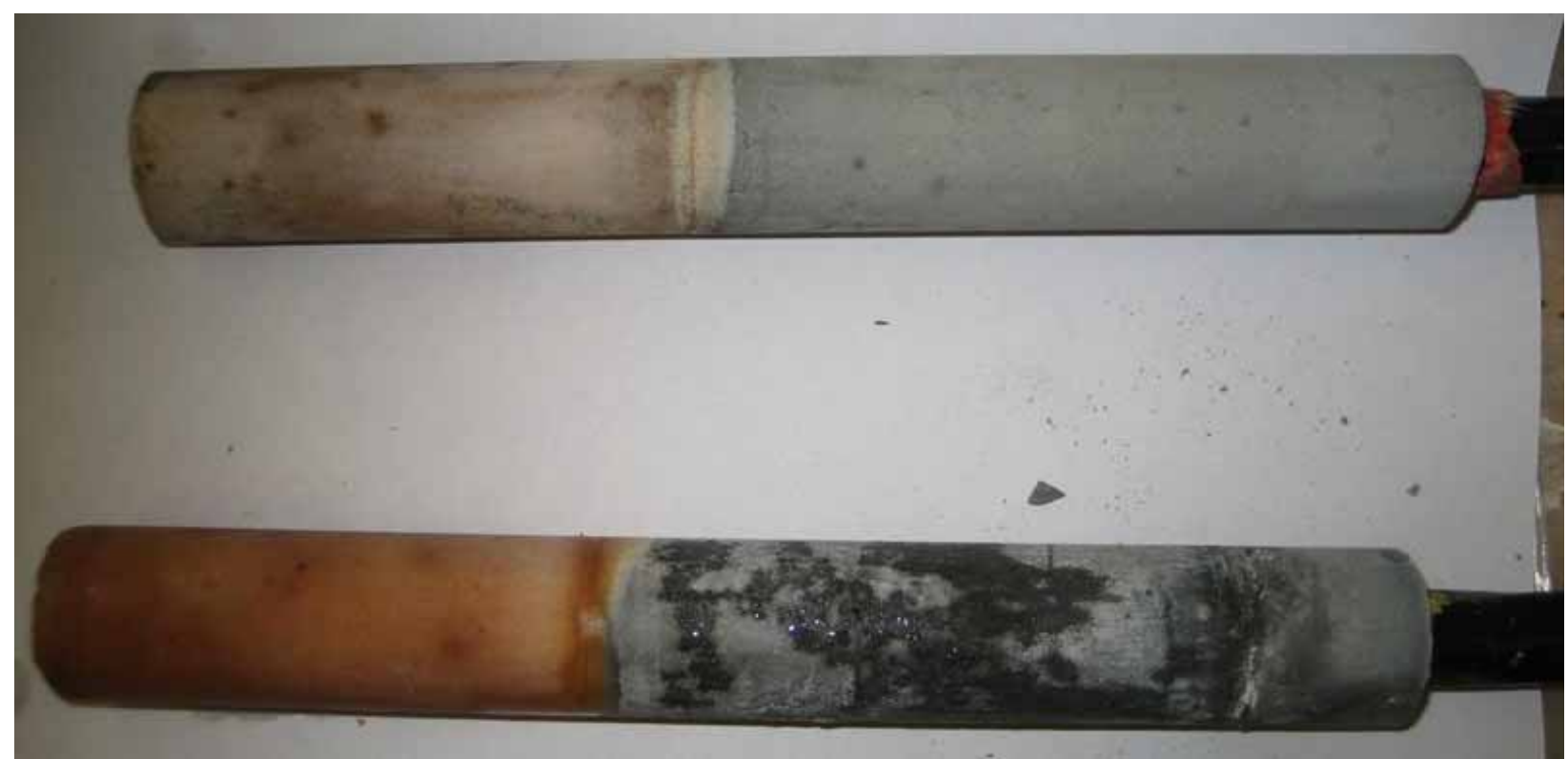

Figure 9e: Specimen S/PC-2, 30 weeks. Strand in Sika grout (top) and portland cement grout (bottom). 


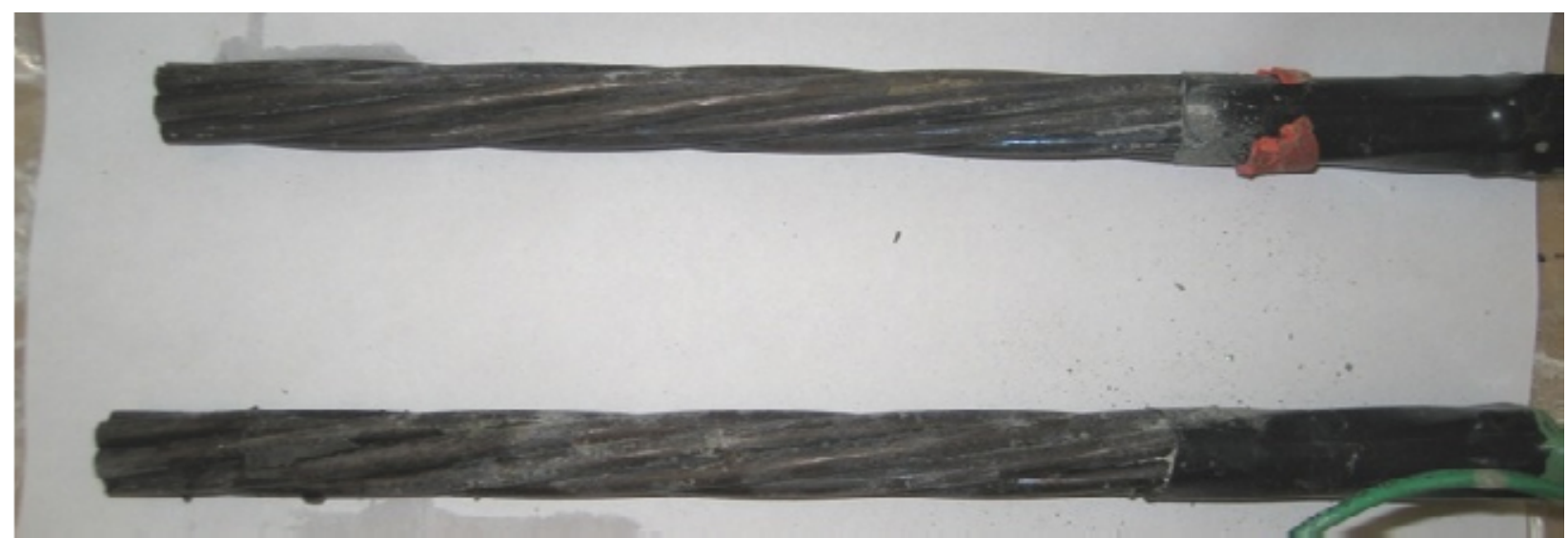

Figure 9f: Specimen S/PC-2, 30 weeks, after removal of grout. Strand in Sika grout (top) and portland cement grout (bottom).

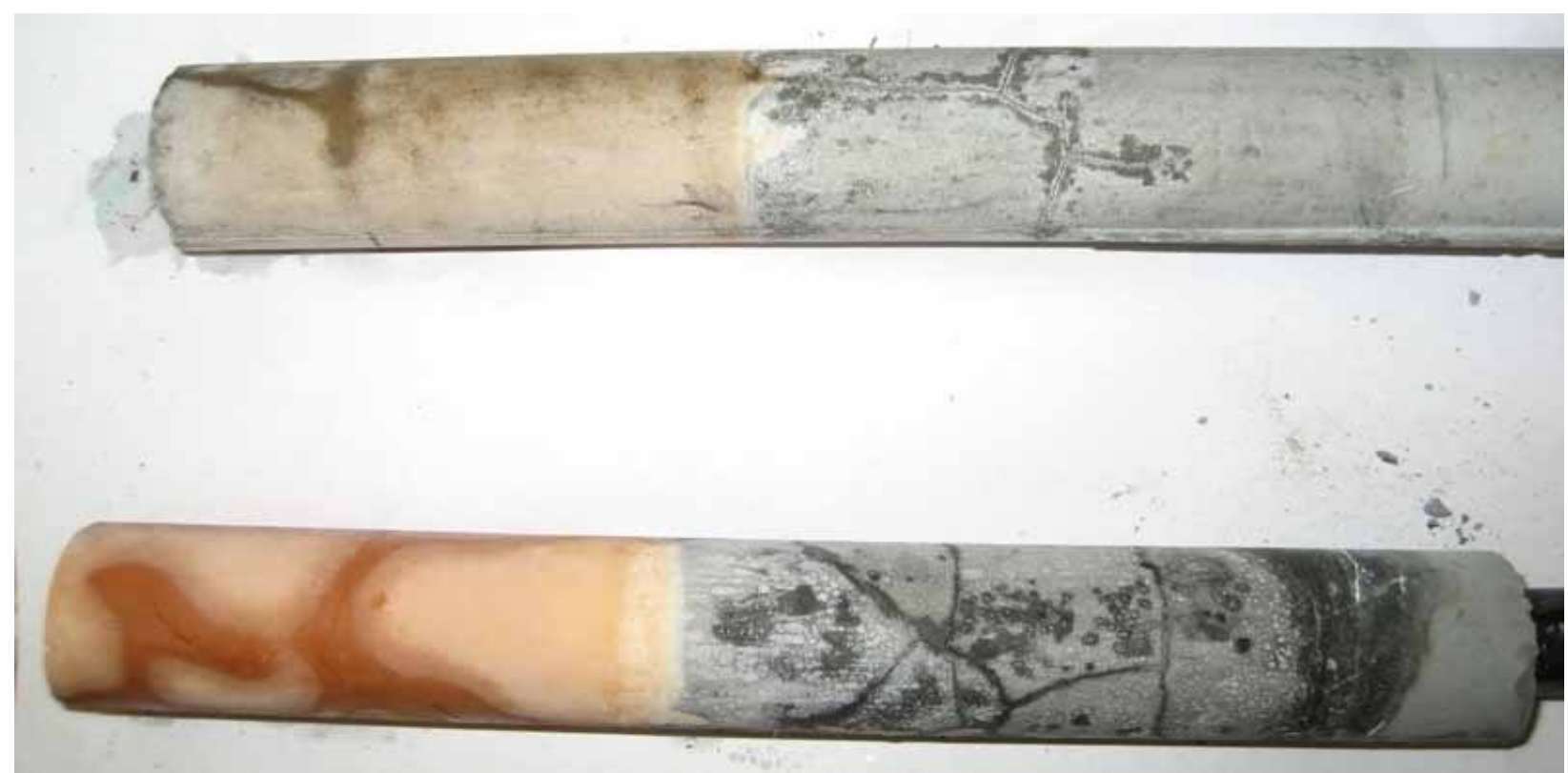

Figure 9g: Specimen SFG/PC-1, 30 weeks. Strand in Sika w/FerroGard grout (top) and portland cement grout (bottom). 


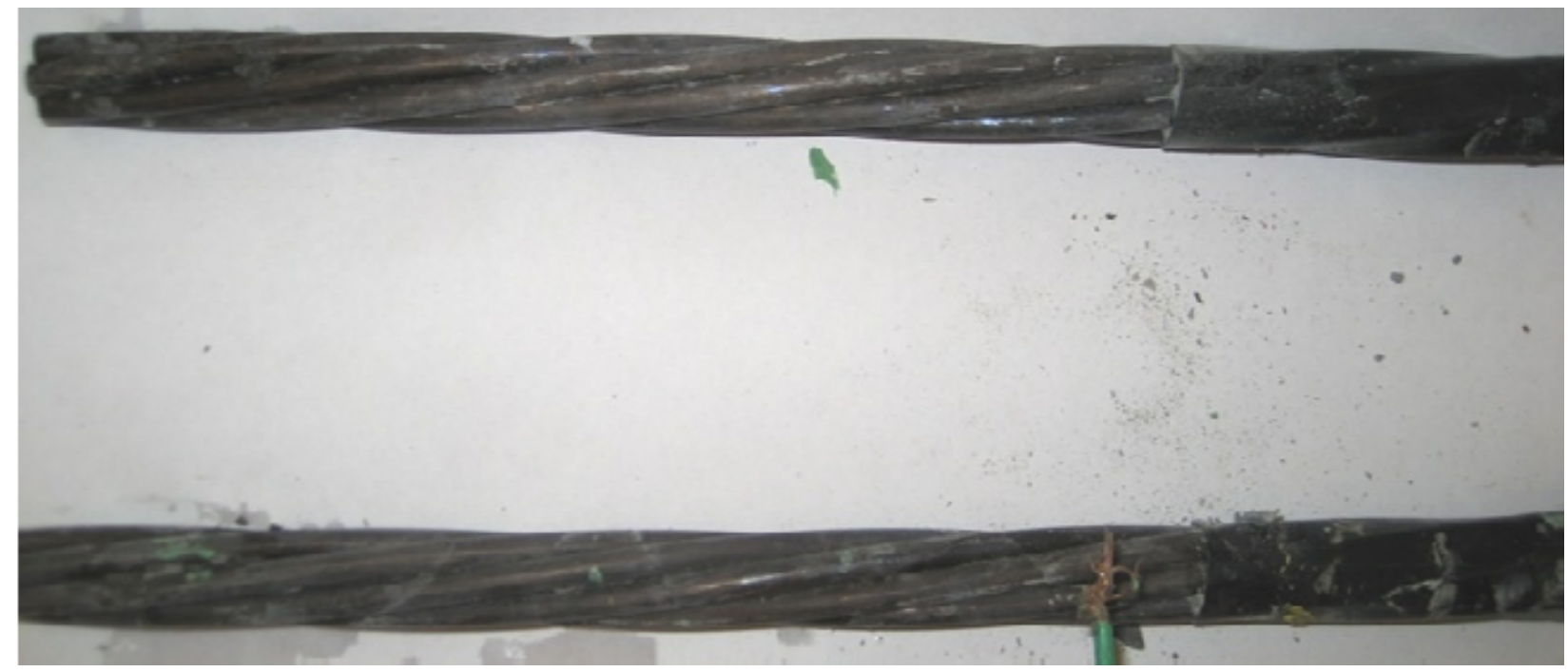

Figure 9h: Specimen SFG/PC-1, 30 weeks, after removal of grout. Strand in Sika w/FerroGard grout (top) and portland cement grout (bottom).

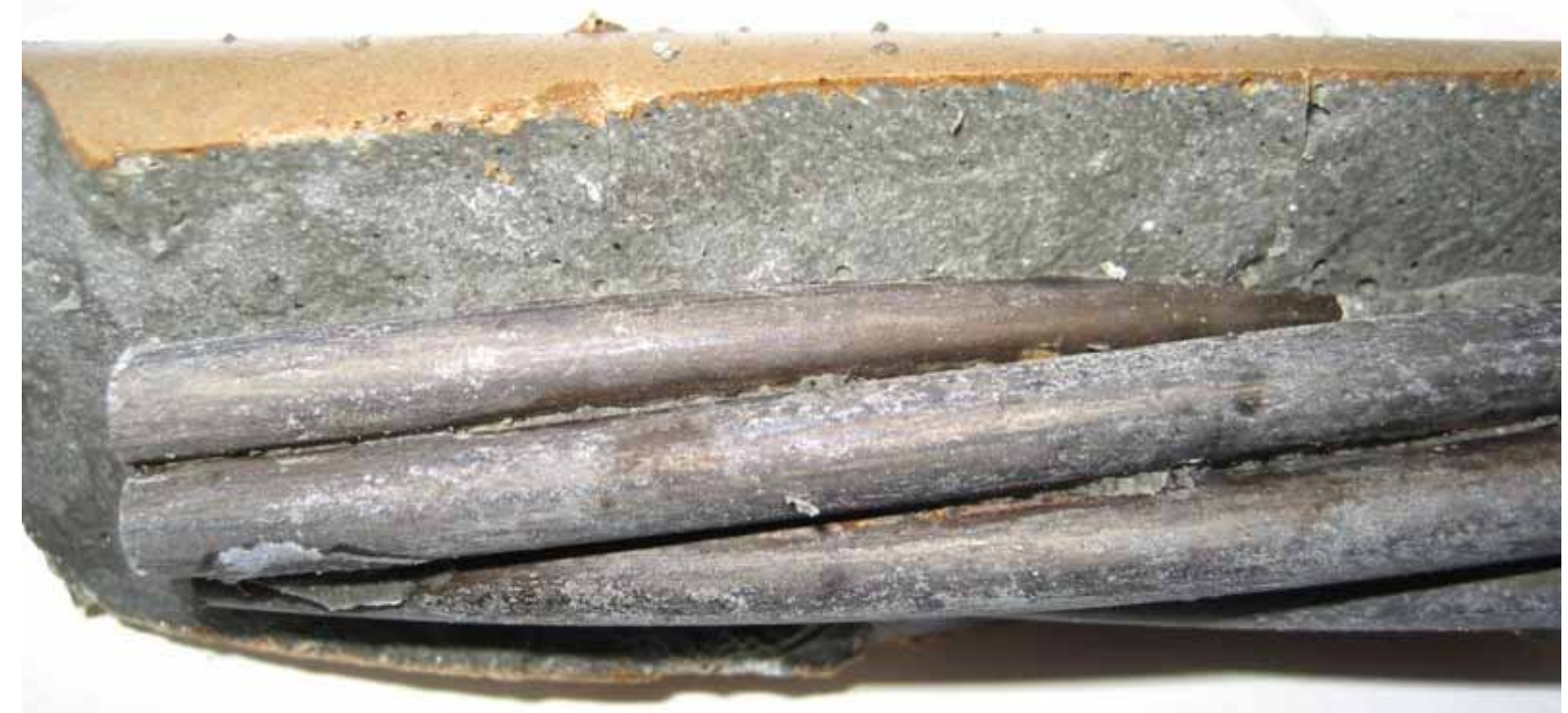

Figure 9i: Staining below the waterline on grout-wrapped specimens.

\section{Bare Strand Exposed to Deionized Water}

The average macrocell corrosion rate for bare prestressing strand in deionized water and simulated portland cement pore solution is shown in Figure 10; corrosion losses for individual specimens at 15 weeks are listed in Table 12. The corrosion rate is cyclic; changing the 
deionized water every 5 weeks resulted in an increase in resistivity of the solution and a corresponding drop in corrosion rate. As corrosion products built up, the resistivity decreased. The peak corrosion rate, $10.6 \mu \mathrm{m} / \mathrm{yr}$, is observed at week 5. The average macrocell corrosion loss at 15 weeks is $2.48 \mu \mathrm{m}$ (Table 12)

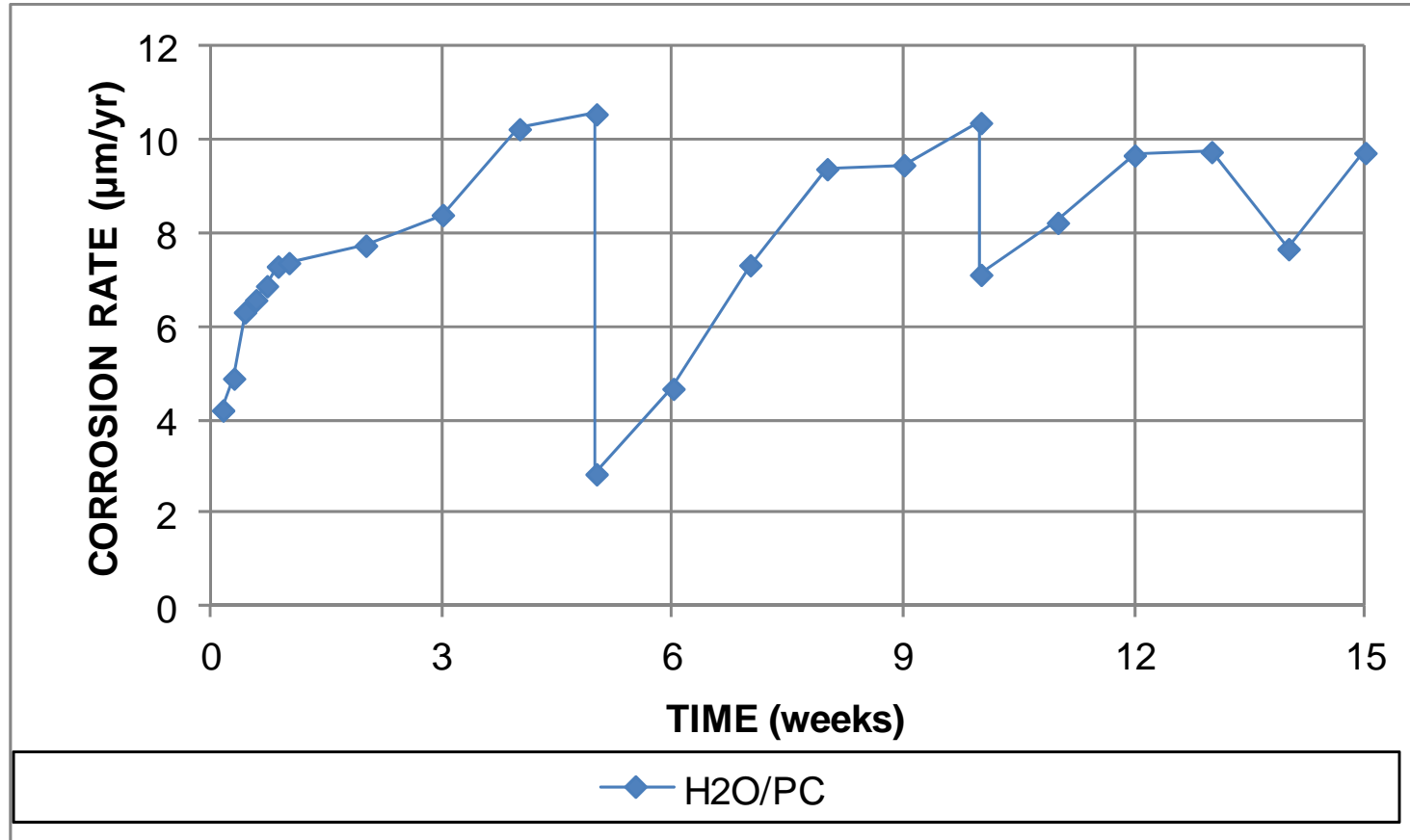

Figure 10: Average macrocell corrosion rates for bare strands in deionized water and simulated portland cement pore solution.

Table 12: Macrocell Corrosion Losses $(\mu \mathrm{m})$ at 15 Weeks for Bare Prestressing Strand in Deionized Water and Simulated Pore Solution

\begin{tabular}{|c|c|c|c|c|c|c|c|c|}
\hline \multirow{2}{*}{ System $^{\mathbf{a}}$} & \multicolumn{5}{|c|}{ Specimen } & \multirow{2}{*}{ Average } & $\begin{array}{c}\text { Standard } \\
\text { Deviation }\end{array}$ \\
\cline { 2 - 9 } & 1 & 2 & 3 & 4 & 5 & 6 & & 0.244 \\
\hline $\mathbf{H}_{2} \mathbf{O} / \mathbf{P C}$ & 2.85 & 2.33 & 2.69 & 2.44 & 2.20 & 2.38 & 2.48 & 0.48 \\
\hline
\end{tabular}

${ }^{\mathbf{a}} \mathrm{H}_{2} \mathrm{O}=$ deionized water, $\mathrm{PC}=$ portland cement

Figure 11 shows the average corrosion potentials for the bare strands in deionized water and simulated portland cement pore solution. The strands in deionized water show an average potential as low as $-0.600 \mathrm{~V}$, far more negative than the strands in the portland cement pore solution, indicating that corrosion is occurring on the former. 


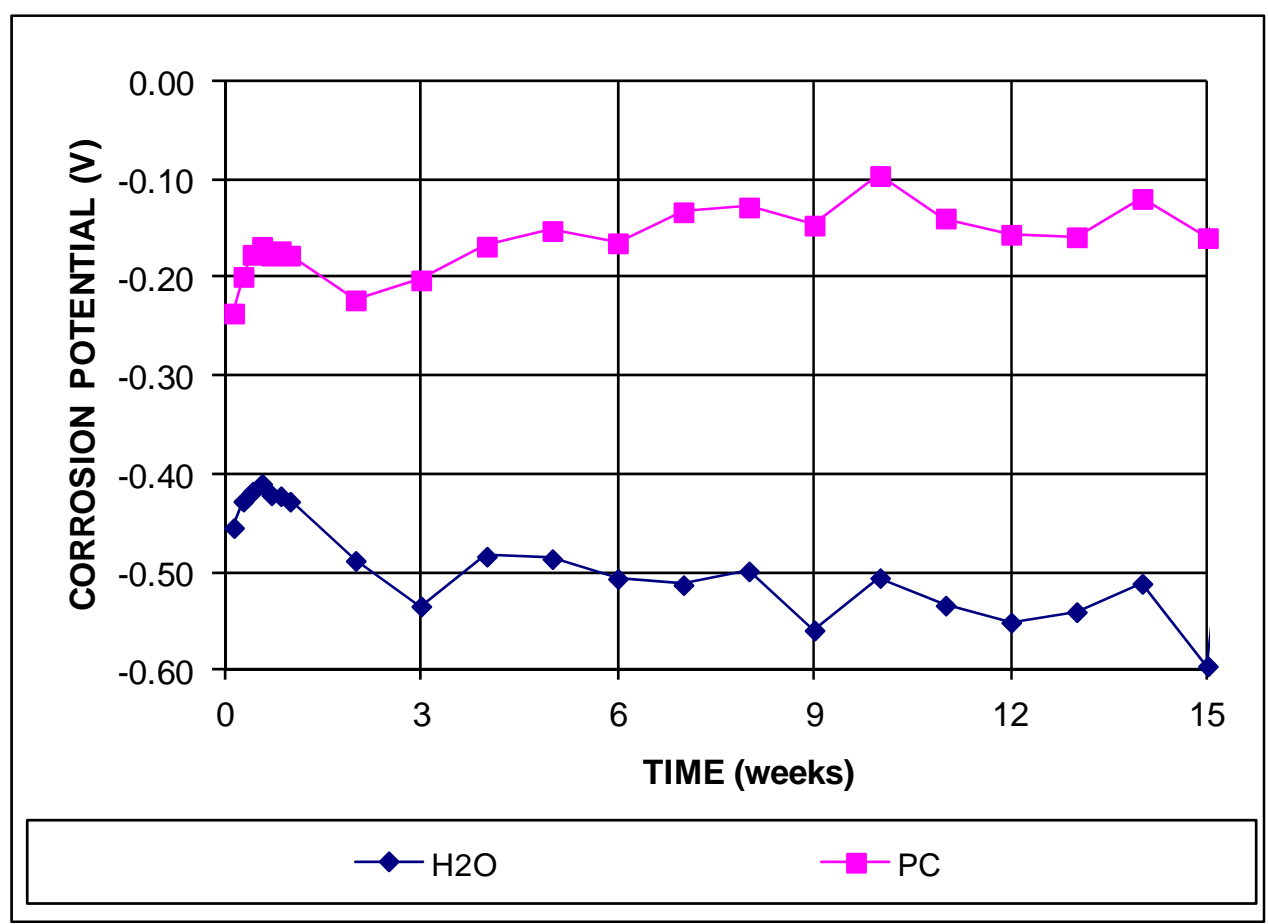

Figure 11: Average corrosion potential (SCE) for bare prestressing strand in deionized water and portland cement grout pore solutions.

The corrosion losses at 15 weeks based on linear polarization resistance are shown in Table 13. The strands in deionized water have an average corrosion loss based on LPR of 10.9 $\mu \mathrm{m}$, while the strands in portland cement pore solution exhibit very low losses $(0.035 \mu \mathrm{m})$.

Table 13: Total (LPR) Corrosion Losses $(\mu \mathrm{m})$ at 15 Weeks for Bare Prestressing Strand in Deionized Water and Simulated Pore Solution

\begin{tabular}{|c|c|c|c|c|c|c|c|c|c|}
\hline \multirow{2}{*}{\multicolumn{2}{|c|}{ System $^{a}$}} & \multicolumn{6}{|c|}{ Specimen } & \multirow{3}{*}{$\begin{array}{c}\text { Average } \\
10.9\end{array}$} & \multirow{3}{*}{$\begin{array}{c}\begin{array}{c}\text { Standard } \\
\text { Deviation }\end{array} \\
6.32\end{array}$} \\
\hline & & \multirow{2}{*}{$\begin{array}{c}1 \\
20.8\end{array}$} & \multirow{2}{*}{$\begin{array}{c}2 \\
7.02\end{array}$} & \multirow{2}{*}{$\begin{array}{c}3 \\
11.6\end{array}$} & \multirow{2}{*}{$\begin{array}{c}4 \\
15.2\end{array}$} & \multirow{2}{*}{$\begin{array}{c}5 \\
3.83\end{array}$} & \multirow{2}{*}{$\begin{array}{c}6 \\
6.76 \\
\end{array}$} & & \\
\hline & $\mathrm{H}_{2} \mathrm{O}$ Strand & & & & & & & & \\
\hline $11_{2}$ & PC Strand & 0.026 & 0.028 & 0.021 & 0.000 & 0.031 & 0.106 & 0.035 & 0.036 \\
\hline
\end{tabular}

${ }^{\mathrm{a}} \mathrm{H}_{2} \mathrm{O}=$ deionized water, $\mathrm{PC}=$ portland cement

Figures $12 \mathrm{a}$ and $12 \mathrm{~b}$ show representative photos of the strands after testing. All strands in deionized water exhibit heavy corrosion below the water line. The strands in simulated portland cement pore solution show no signs of corrosion after testing. 


\section{$\mathrm{H}_{2} \mathrm{O}-\mathrm{PC}-2$}

Figure 12a: Specimen $\mathrm{H}_{2} \mathrm{O} / \mathrm{PC}-1$, 15 weeks. Strand in deionized water (top) and simulated portland cement pore solution (bottom).

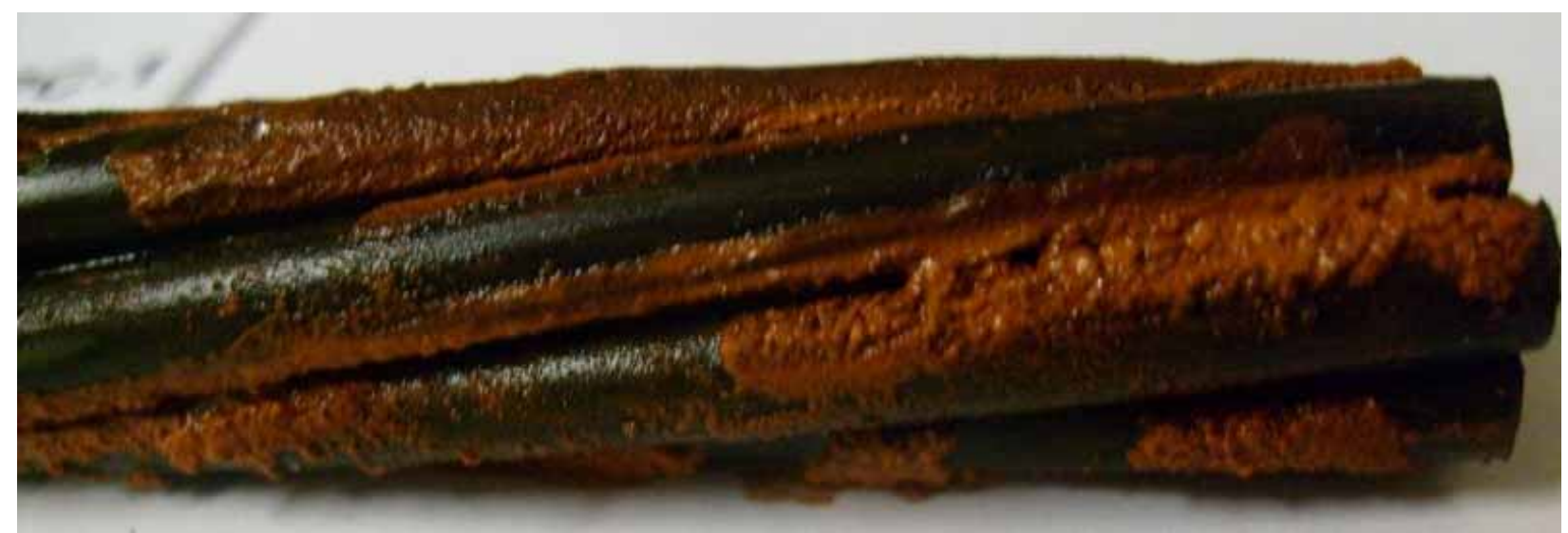

Figure 12b: Specimen $\mathrm{H}_{2} \mathrm{O} / \mathrm{PC}-1$, 15 weeks. Close-up of strand in deionized water.

\section{Strands in Chloride-Contaminated Pore Solution}

Figure 13 shows the average corrosion rate for bare strands in pore solutions containing $3 \%$ chlorides by weight. Losses at 15 weeks are given in Table 14 . The SFG/PC w/salt specimens show average macrocell corrosion rates between -8 and $-15 \mu \mathrm{m} / \mathrm{yr}$ (negative rates indicate the corrosion is occurring on the portland cement strand), while the NA/PC w/salt specimens show rates averaging between -6 and $+4 \mu \mathrm{m} / \mathrm{yr}$. These rates are not indicative of low 
overall corrosion; rather, they suggest heavy corrosion occurring at an approximately equal rate on both strands, as suggested by corrosion potential, LPR, and autopsy results.

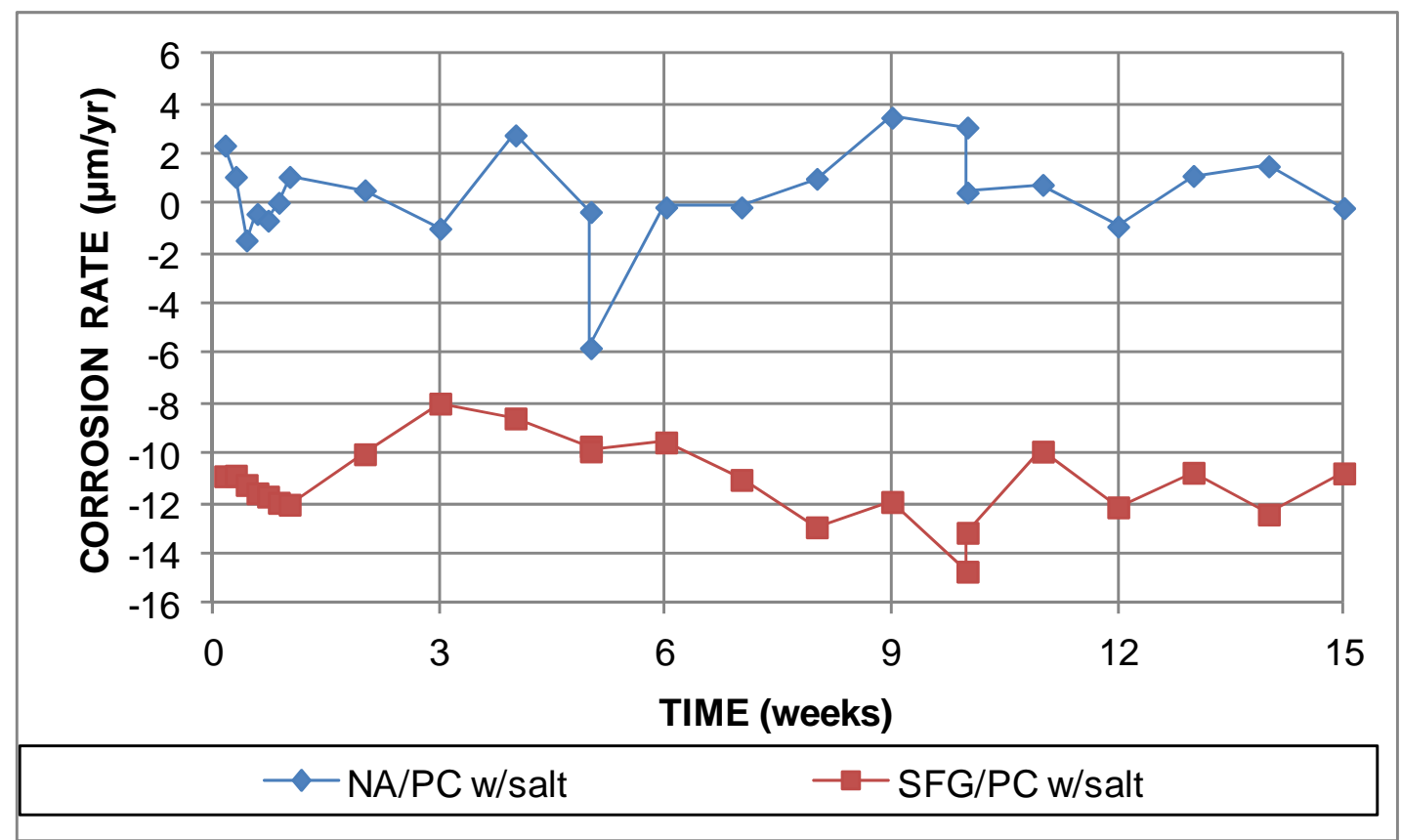

Figure 13: Average macrocell corrosion rates for bare strands in deionized water and simulated portland cement pore solution.

Table 14: Macrocell Corrosion Losses $(\mu \mathrm{m})$ at 15 Weeks for Bare Prestressing Strand in Simulated Pore Solution with 3\% Chlorides

\begin{tabular}{|c|c|c|c|c|c|c|c|c|}
\hline \multirow{2}{*}{ System $^{\mathbf{a}}$} & \multicolumn{5}{|c|}{ Specimen } & \multirow{2}{*}{ Average } & $\begin{array}{c}\text { Standard } \\
\text { Deviation }\end{array}$ \\
\cline { 2 - 8 } & 1 & 2 & 3 & 4 & 5 & 6 & & 0.351 \\
\hline NA/PC w/salt & 0.281 & 0.518 & 0.224 & 0.441 & 0.355 & -0.456 & 0.227 & 1.12 \\
\hline SFG/PC w/salt & -3.04 & -3.24 & -3.51 & -4.80 & -1.30 & -2.97 & -3.14 & 14 \\
\hline
\end{tabular}

${ }^{\mathrm{a}} \mathrm{PC}=$ portland cement, $\mathrm{SFG}=$ Sika $\mathrm{w} /$ FerroGard, NA $=$ US Mix NA-50.

Figures $14 \mathrm{a}-14 \mathrm{~b}$ show the average corrosion potentials for the bare strands exposed to salt. For the NA/PC w/salt specimens, the strands in the simulated NA and portland cement grout pore solutions have similar potentials, averaging around $-0.50 \mathrm{~V}$ for most of the test. This suggests that active corrosion is occurring on both strands in the macrocell. For SFG/PC w/salt, 


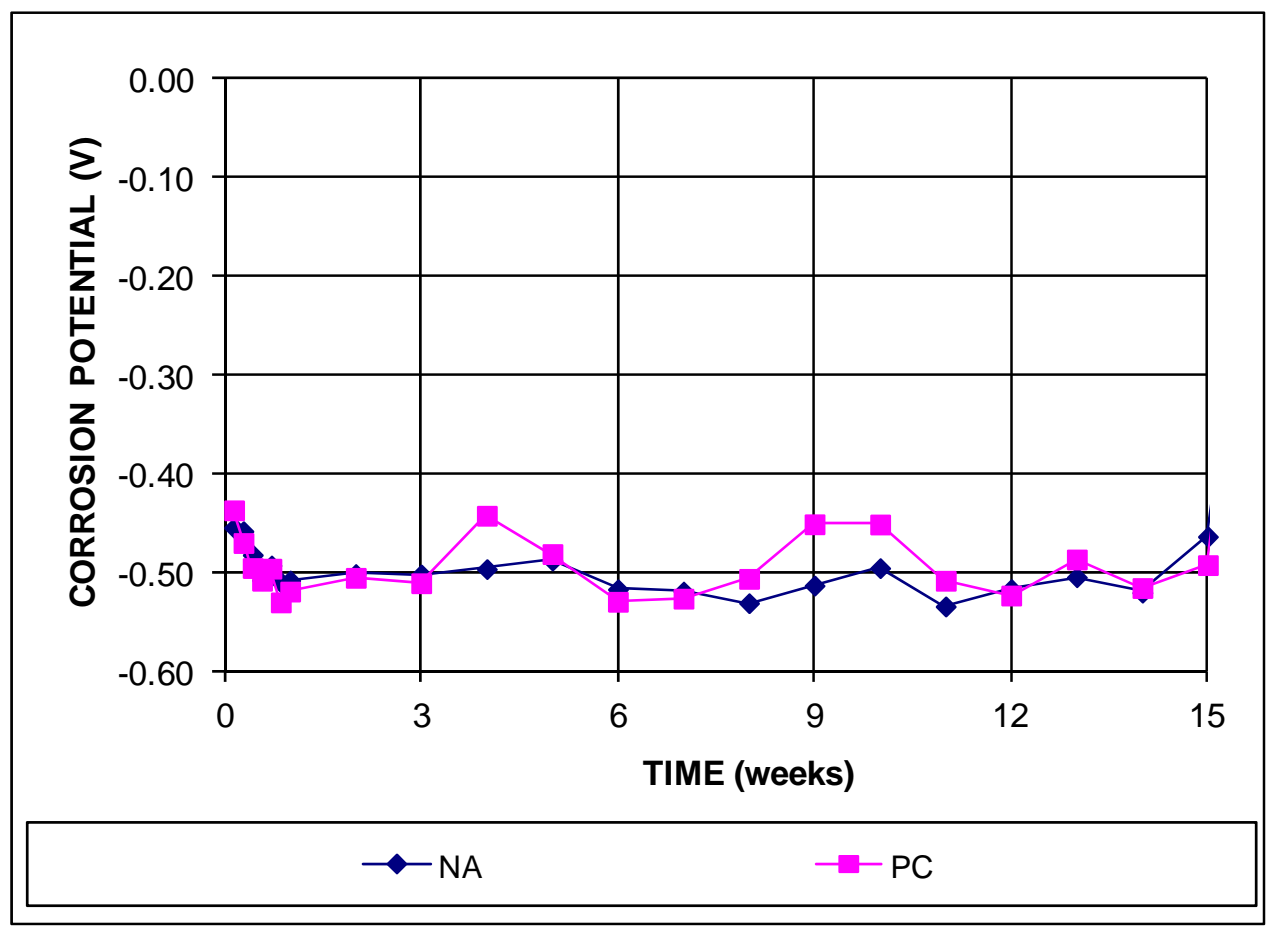

Figure 14a: Average corrosion potential (SCE) for bare prestressing strand in simulated NA and portland cement grout pore solutions with $3 \%$ salt.

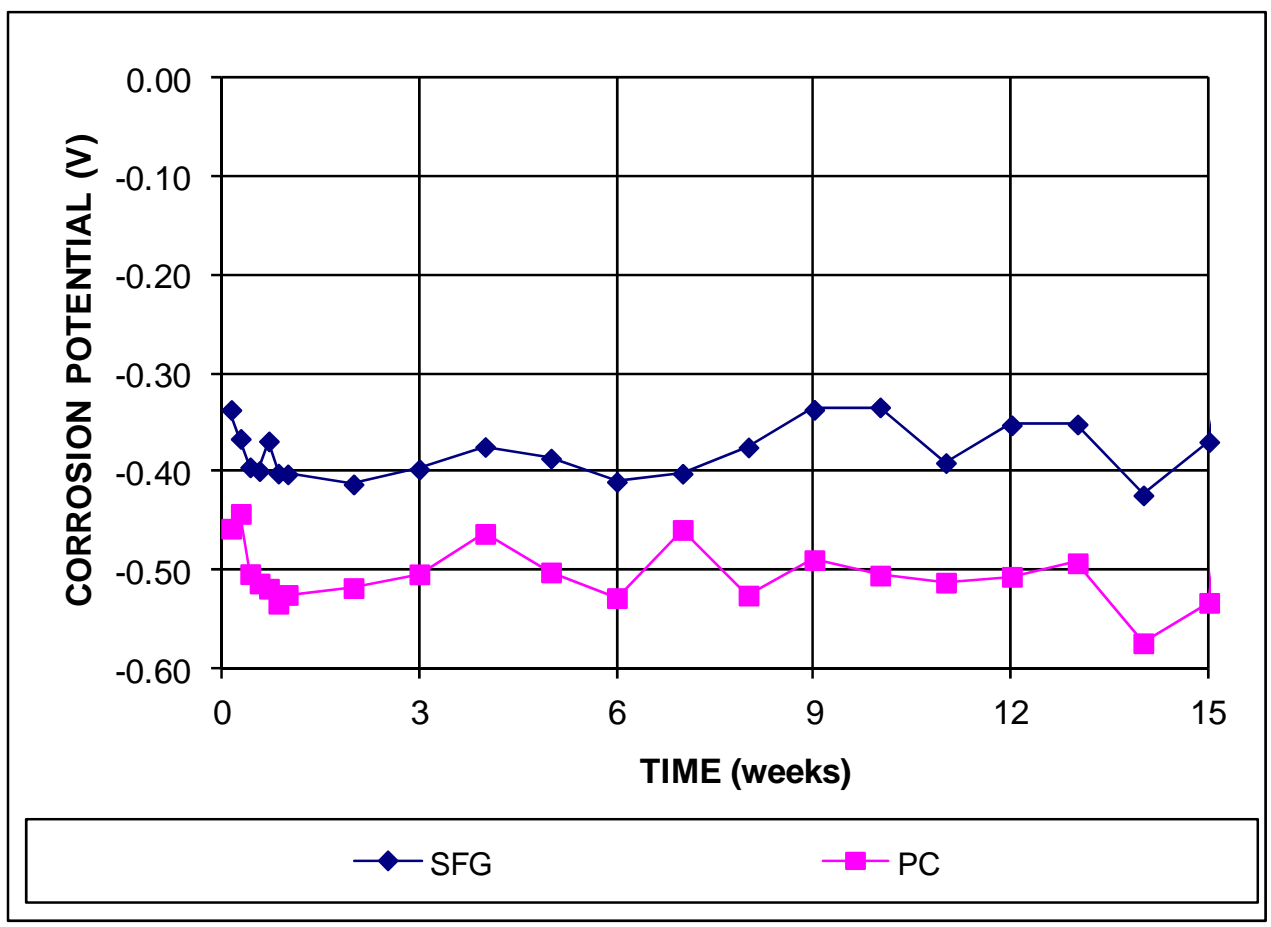

Figure 14b: Average corrosion potential (SCE) for bare prestressing strand in simulated Sika w/FerroGard and portland cement grout pore solutions with $3 \%$ salt. 
the strands in the portland cement pore solution also have an average potential of about $-0.50 \mathrm{~V}$. However, the strands in simulated Sika w/FerroGard pore solution have a slightly less negative potential, $-0.40 \mathrm{~V}$. While this still indicates active corrosion, it also indicates that the Sika w/FerroGard solution provides some protection against corrosion, perhaps due to its higher $\mathrm{pH}$.

The corrosion losses at 15 weeks based on linear polarization resistance are shown in Table 15. At 15 weeks, all specimens show high corrosion losses. The strands in portland cement pore solution with $3 \%$ salt from the $\mathrm{SFG} / \mathrm{PC}$ w/salt specimens show the greatest average losses, $19.8 \mu \mathrm{m}$. The strands in Sika w/FerroGard pore solution show the lowest average losses, 3.90 $\mu \mathrm{m}$. The NA and PC strands from the NA/PC w/salt specimens show average losses of 17.0 and $15.8 \mu \mathrm{m}$, respectively. These results, in conjunction with the corrosion potentials, indicate rapid corrosion on the strands when they are exposed to salt.

Table 15: Total (LPR) Corrosion Losses ( $\mu \mathrm{m})$ at 15 Weeks for Bare Prestressing Strand in Simulated Pore Solution with salt.

\begin{tabular}{|c|c|c|c|c|c|c|c|c|c|}
\hline \multicolumn{2}{|c|}{ System $^{\mathbf{a}}$} & \multicolumn{6}{|c|}{ Specimen } & \multirow{2}{*}{ Average } & $\begin{array}{c}\text { Standard } \\
\text { Deviation }\end{array}$ \\
\cline { 3 - 10 } & 1 & 2 & 3 & 4 & 5 & 6 & & 3.69 \\
\hline \multirow{2}{*}{ NA/PC w/salt } & NA Strand & 18.8 & 16.8 & 19.8 & 20.7 & 15.3 & 10.7 & 17.0 & 7.62 \\
\cline { 2 - 10 } & PC Strand & 18.5 & 13.5 & 29.6 & 8.65 & 9.94 & 14.7 & 15.8 & 1.70 \\
\hline \multirow{2}{*}{ SFG/PC w/salt } & SFG Strand & 2.62 & 2.85 & 3.46 & 2.91 & 7.10 & 4.44 & 3.90 & 5.00 \\
\cline { 2 - 9 } & PC Strand & 21.1 & 27.0 & 11.6 & 18.9 & 21.3 & 19.1 & 19.8 & \\
\hline
\end{tabular}

${ }^{\mathbf{a}} \mathrm{PC}=$ portland cement, $\mathrm{SFG}=$ Sika $\mathrm{w} /$ FerroGard, NA $=$ US Mix NA-50.

Figures $15 \mathrm{a}-15 \mathrm{f}$ show representative photos of the strands exposed to the $\mathrm{NaCl}$ solution after testing. Heavy corrosion products appear on both strands for each combination. For the $\mathrm{NA} / \mathrm{PC}$ w/salt specimens, there appears to be a roughly equal quantity of corrosion products on the strands in NA and PC pore solutions (Figures $15 \mathrm{~b}, 15 \mathrm{c}$ ). For the $\mathrm{SFG} / \mathrm{PC}$ w/salt specimens, the strands in SFG pore solution appear to have less corrosion products (Figure 15e) than those in PC pore solution (Figure 15f), matching the corrosion potential and LPR results. 


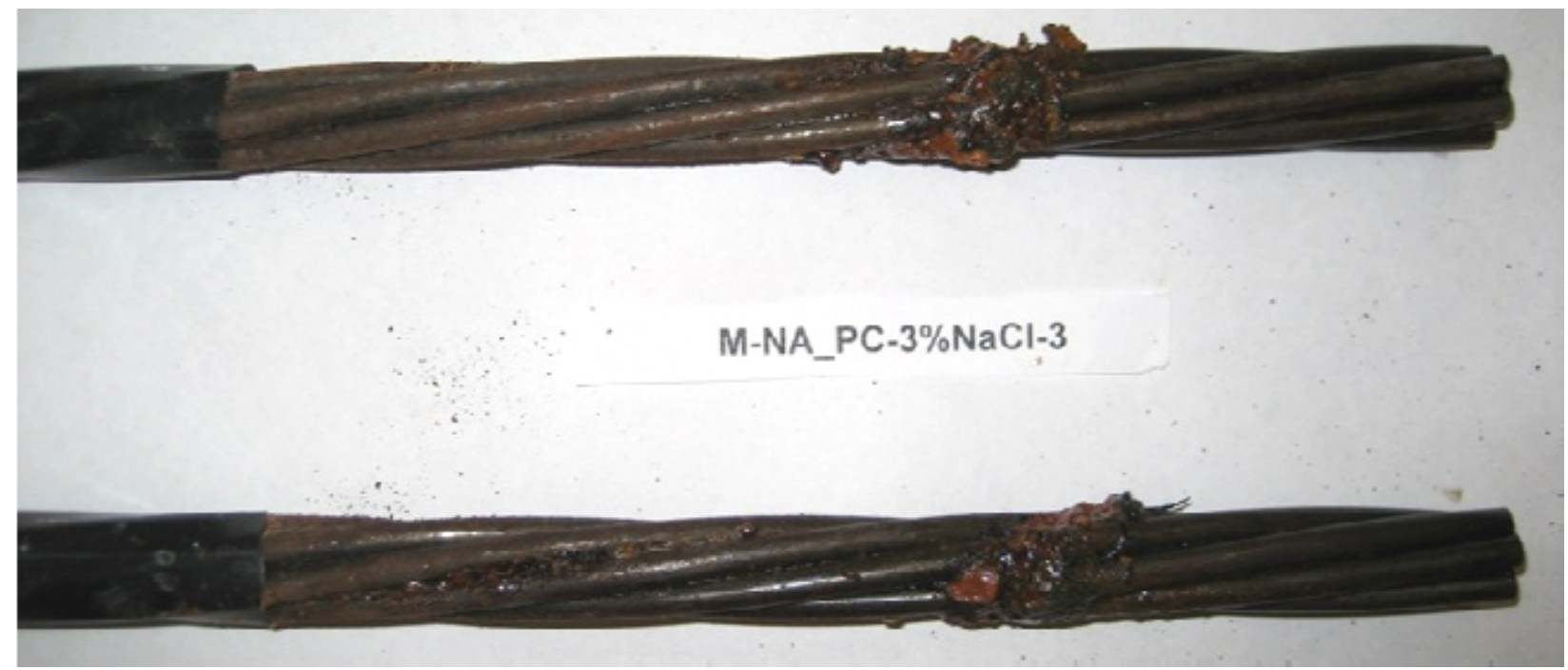

Figure 15a: Specimen NA/PC w/salt-3, 15 weeks. Strand in simulated NA (top) and portland cement pore (bottom) solutions with $3 \% \mathrm{NaCl}$.

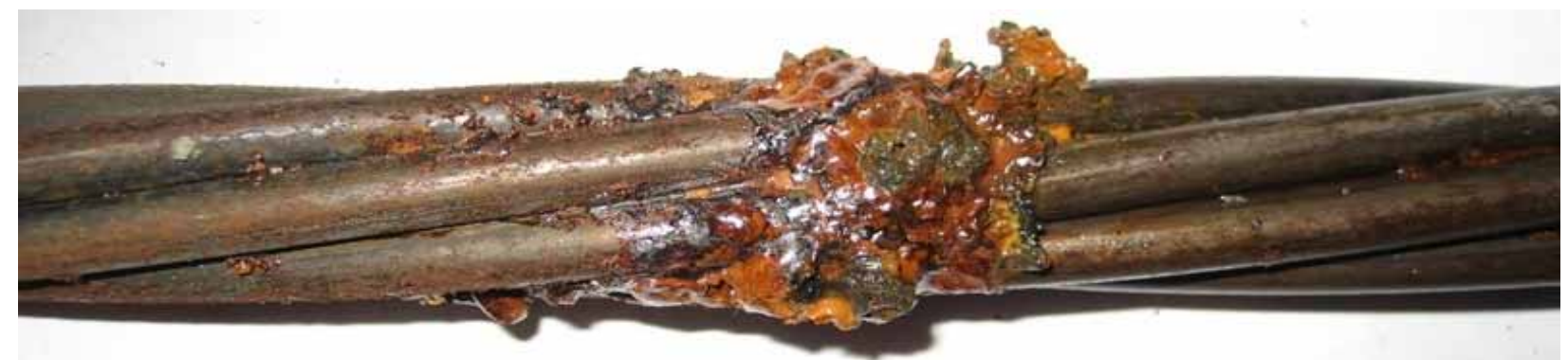

Figure 15b: Specimen NA/PC w/salt-3, 15 weeks. Close-up of strand in simulated NA pore solution with $3 \% \mathrm{NaCl}$.

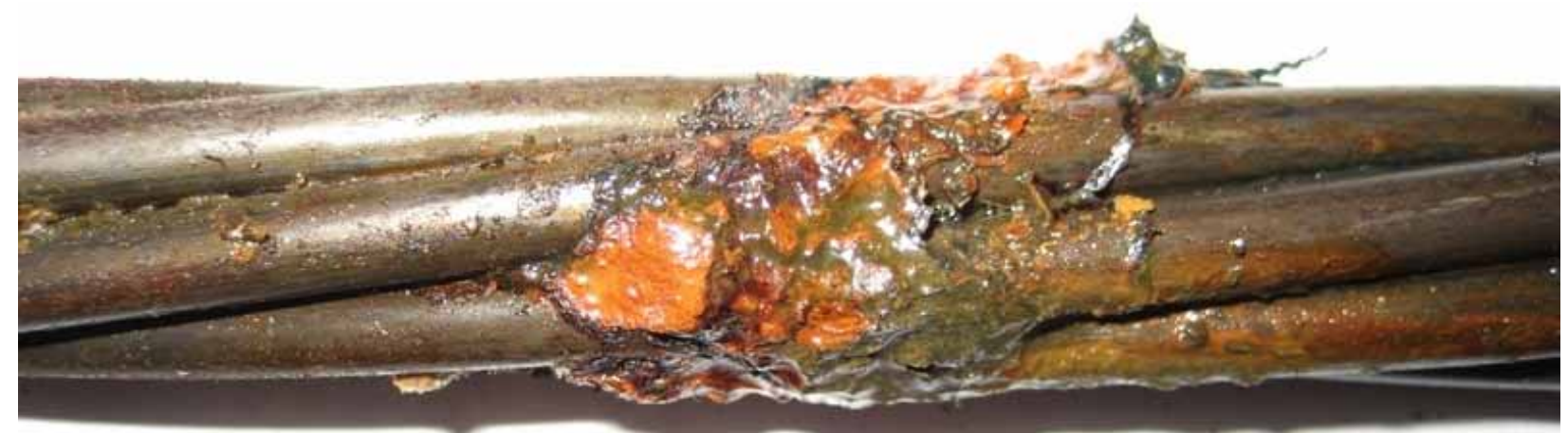

Figure 15c: Specimen NA/PC w/salt-3, 15 weeks. Close-up of strand in simulated portland cement pore solution with $3 \% \mathrm{NaCl}$. 


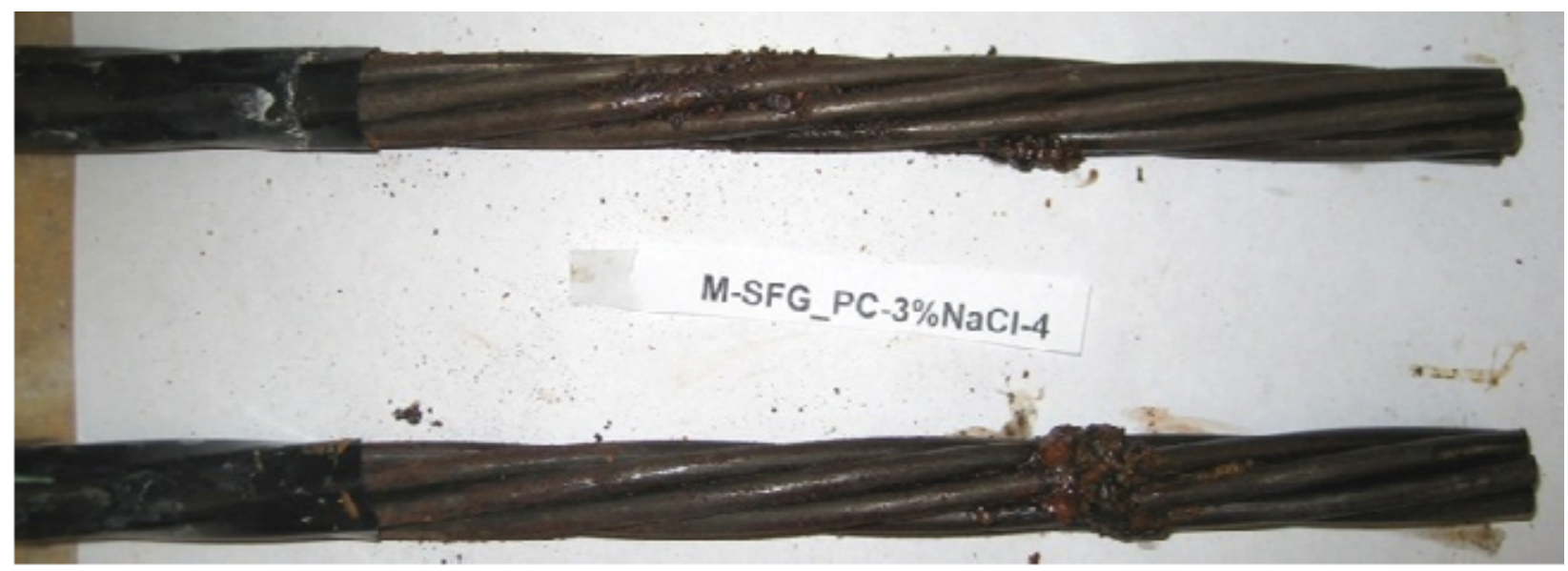

Figure 15d: Specimen SFG/PC w/salt-4, 15 weeks. Strand in simulated Sika w/FerroGard (top) and portland cement pore (bottom) solutions with $3 \% \mathrm{NaCl}$.

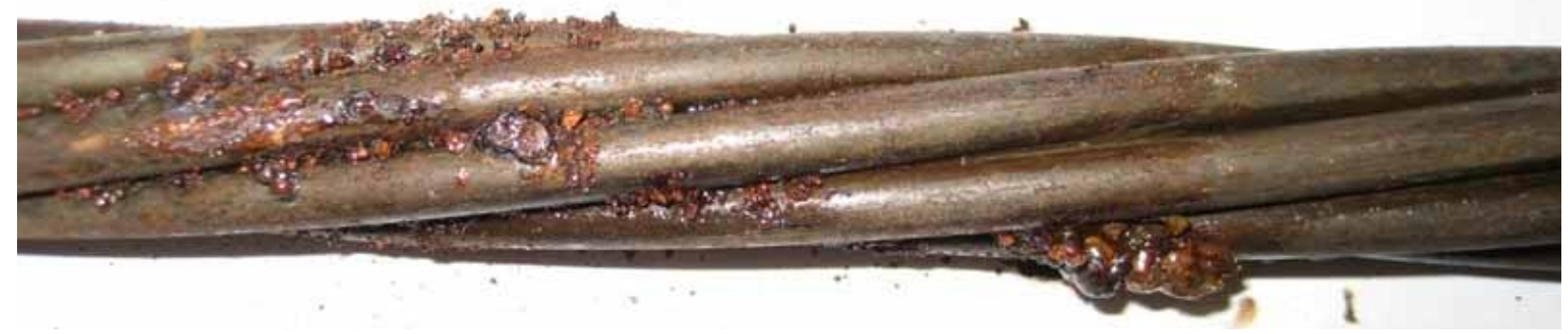

Figure 15e: Specimen SFG/PC w/salt-4, 15 weeks. Close-up of strand in simulated Sika w/FerroGard pore solution with $3 \% \mathrm{NaCl}$.

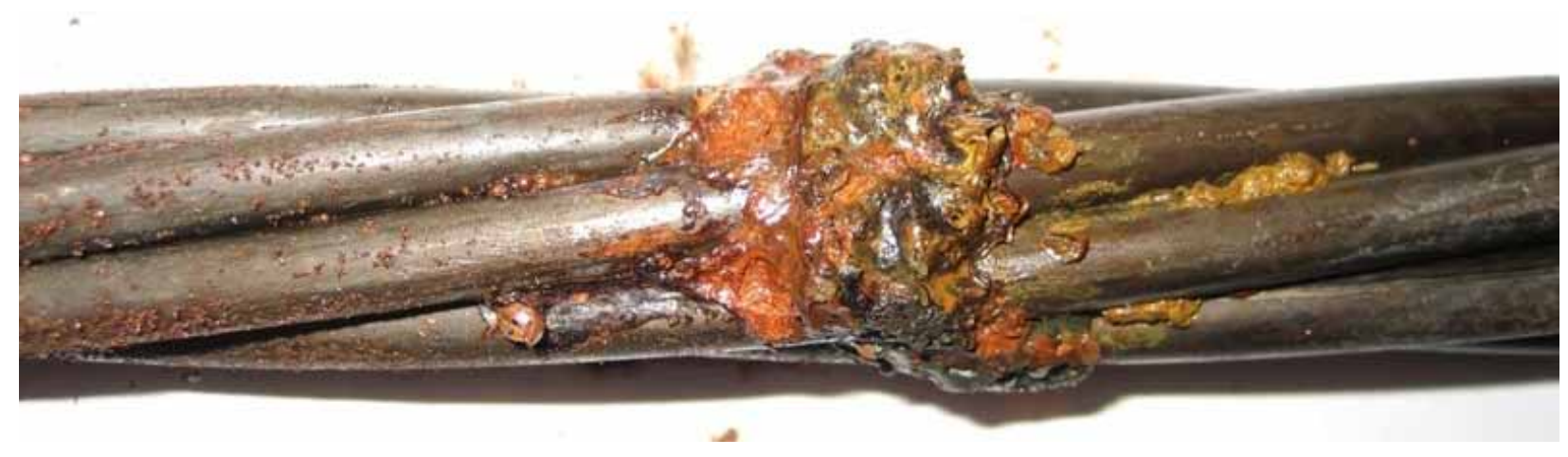

Figure 15f: Specimen SFG/PC w/salt-4, 15 weeks. Close-up of strand in simulated portland cement pore solution with $3 \% \mathrm{NaCl}$. 


\section{DISCUSSION}

The total losses based on linear polarization resistance are summarized in Table 16. The greatest corrosion losses are observed on strands exposed to salt- $-19.8 \mu \mathrm{m}$ and $15.8 \mu \mathrm{m}$ for the strands in simulated portland cement pore solution in the $\mathrm{SFG} / \mathrm{PC} \mathrm{w} / \mathrm{salt}$ and $\mathrm{NA} / \mathrm{PC} \mathrm{w} / \mathrm{salt}$ tests, and $17.0 \mu \mathrm{m}$ for the strands in simulated NA pore solution in the NA/PC w/salt test. High corrosion losses, $10.9 \mu \mathrm{m}$, are also observed for strands in deionized water. These results suggest that protecting the strands from the elements is critical to avoiding rapid corrosion. Exposed strands that are kept dry would likely fare better than those tested in this study.

In the absence of salt, the strands in the simulated pore solutions for the anti-bleed commercial grouts and portland cement grout exhibit lower losses, with LPR losses averaging $1.65 \mu \mathrm{m}$ or less, and with most specimens exhibiting losses below $1 \mu \mathrm{m}$. This observation also holds for the S/PC and SFG/PC grout-wrapped specimen tests. The highest average loss, 1.65 $\mu \mathrm{m}$, occurs for the strands exposed to the simulated NA grout pore solution, the pore solution with the highest sulfate content, and as shown in Figure 16, the LPR losses for strands in the simulated anti-bleed commercial grout pore solutions coupled with strands in simulated portland cement pore solution increase with sulfate ion concentration. In only two cases, the SFG/PC pore solution tests with and without salt, does the average LPR loss of the strands associated with portland cement grout exceed that of the strands in the other grout.

In contrast to the strands in the anti-bleed commercial grouts (or their simulated pore solutions), the strands in gypsum grout and simulated gypsum grout pore solution exhibit high corrosion losses, similar to the strands in deionized water. In this study, the gypsum grouts and pore solutions were coupled with portland cement or Sika w/FerroGard grouts and pore solutions. It is likely that the corrosion of the strands exposed to gypsum results from a 
combination of effects: the more negative corrosion potential caused by differences in grout $\mathrm{pH}$, the low $\mathrm{pH}$ (13.0) of gypsum grout itself, and the elevated sulfate content of the gypsum pore solution. The single series in which simulated pore solution from NA grout, with its very high sulfate content, is coupled with simulated pore solution from portland cement, NA/PC, suggests

Table 16: Total (LPR) Corrosion Losses $(\mu \mathrm{m})$ at 15 Weeks for Prestressing Strand.

\begin{tabular}{|c|c|c|c|}
\hline \multicolumn{2}{|c|}{ System $^{\mathrm{a}}$} & \multirow{2}{*}{$\begin{array}{c}\text { Average } \\
9.17\end{array}$} & \multirow{2}{*}{$\begin{array}{c}\text { Standard } \\
\text { Deviation }\end{array}$} \\
\hline \multirow{2}{*}{ G/PC } & G Strand & & \\
\hline & PC Strand & 0.363 & 0.179 \\
\hline \multirow{2}{*}{ G/SFG } & G Strand & 11.3 & 12.4 \\
\hline & SFG Strand & 0.442 & 0.289 \\
\hline \multirow{2}{*}{ Euco/PC } & Euco Strand & 0.785 & 0.365 \\
\hline & PC Strand & 0.294 & 0.166 \\
\hline \multirow{2}{*}{ NA/PC } & NA Strand & 1.65 & 0.945 \\
\hline & PC Strand & 1.05 & 1.55 \\
\hline \multirow{2}{*}{$\mathrm{S} / \mathrm{PC}$} & S Strand & 0.999 & 0.333 \\
\hline & PC Strand & 0.370 & 0.169 \\
\hline \multirow{2}{*}{ SFG/PC } & SFG Strand & 0.537 & 0.149 \\
\hline & PC Strand & 0.676 & 0.449 \\
\hline \multirow{2}{*}{ G/SFG (grout) } & G Strand & 7.60 & 2.06 \\
\hline & SFG Strand & 0.237 & 0.101 \\
\hline \multirow{2}{*}{ S/PC (grout) } & S Strand & 0.88 & 0.177 \\
\hline & PC Strand & 0.40 & 0.046 \\
\hline \multirow{2}{*}{ SFG/PC (grout) } & SFG Strand & 0.78 & 0.232 \\
\hline & PC Strand & 0.46 & 0.157 \\
\hline \multirow{2}{*}{$\mathrm{H}_{2} \mathrm{O} / \mathrm{PC}$} & $\mathrm{H}_{2} \mathrm{O}$ Strand & 10.9 & 6.32 \\
\hline & PC Strand & 0.035 & 0.036 \\
\hline \multirow{2}{*}{ NA/PC (w/ salt) } & NA Strand & 17.0 & 3.69 \\
\hline & PC Strand & 15.8 & 7.62 \\
\hline \multirow{2}{*}{ SFG/PC (w/ salt) } & SFG Strand & 3.90 & 1.70 \\
\hline & PC Strand & 19.8 & 5.00 \\
\hline
\end{tabular}

${ }^{\mathrm{a}}$ In simulated pore solution unless grout is indicated. $\mathrm{H}_{2} \mathrm{O}=$ deionized water, $\mathrm{PC}=$ portland cement, $\mathrm{G}=$ gypsum, Euco $=$ Euco Cable Grout, $\mathrm{S}=\mathrm{Sika}, \mathrm{SFG}=\mathrm{Sika}$ w/FerroGard, NA = US Mix NA-50. 


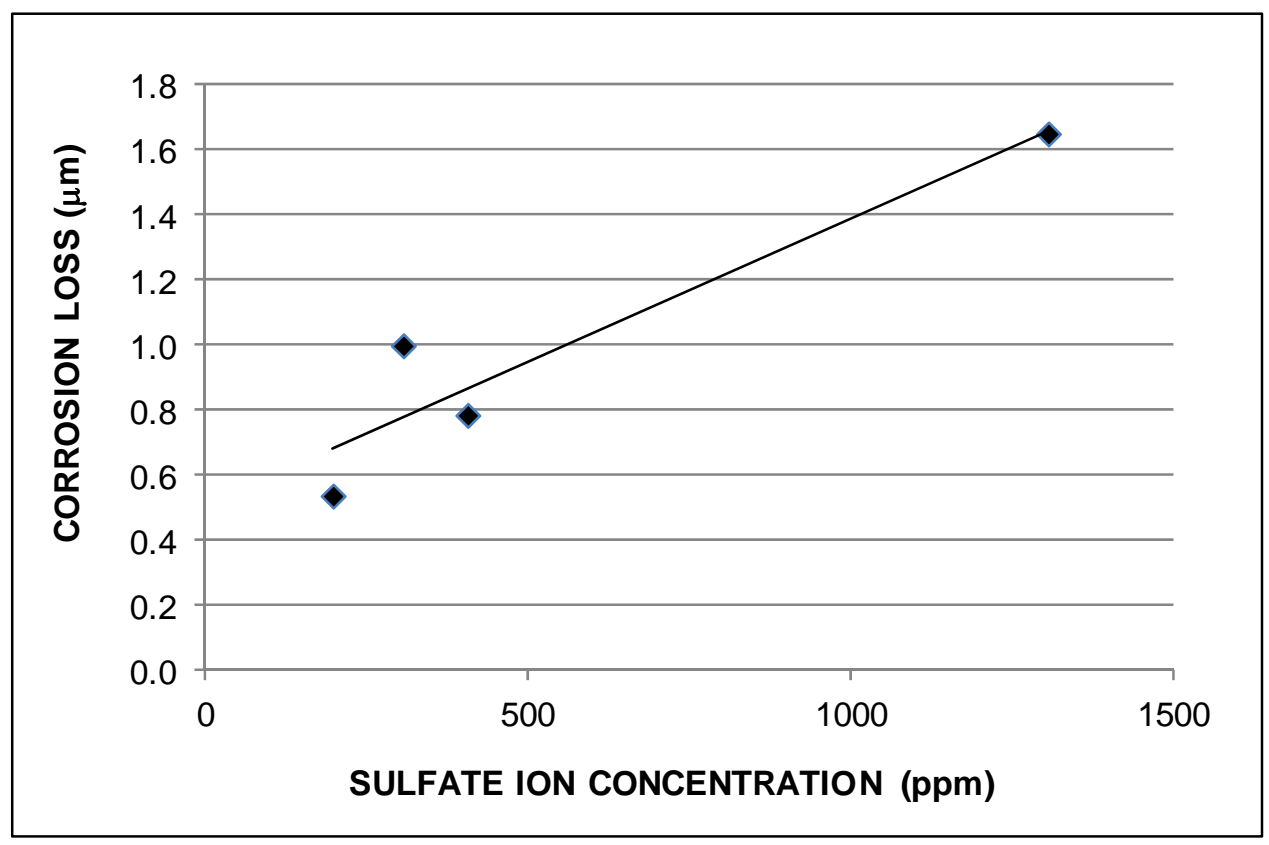

Figure 16: Total (LPR) corrosion losses at 15 weeks for strands in simulated anti-bleed commercial grout pore solutions paired with strands in simulated portland cement pore solution versus sulfate ion concentration.

that $\mathrm{pH}$ has a greater effect than sulfate content, at least for grouts with the ranges of $\mathrm{pH}$ and sulfate ion concentration evaluated in this study. The poor performance of gypsum in this study suggests that it will cause significant corrosion if paired with any of the grouts tested.

When paired with portland cement grout, the prepackaged anti-bleed grouts evaluated in this study resulted in low corrosion losses-losses that, nevertheless, increased with increasing pore solution sulfate ion concentration. The $\mathrm{pH}$ of portland cement grout pore solution (13.5) appears to be high enough to minimize the potential for corrosion resulting from exposure to the anti-bleed grouts with pore solution $\mathrm{pH}$ values between 13.35 and 13.98 . Overall, the results indicate that the sulfate concentration of anti-bleed grout pore solutions should be monitored and that care should be taken to ensure that the anti-bleed repair grout and the existing grout pore solutions have similar $\mathrm{pH}$ values. 


\section{SUMMARY AND CONCLUSIONS}

Portland cement grout, gypsum grout, and four commercially available prepackaged grouts (NA-50 grout, produced by US Mix; Euco Cable Grout PTX, produced by Euclid Chemical; SikaGrout 300 PT, produced by Sika Corp.; and Sika grout with Sika FerroGard, a corrosion-reducing admixture) were analyzed to determine the chemical composition of the resulting pore solutions and tested to determine if using a second grout will provide improved corrosion protection for prestressing strands or result in accelerated corrosion. The potential consequences of leaving voids unfilled were also evaluated. Pore solutions were analyzed for $\mathrm{pH}$ and sodium, potassium, fluoride, chloride, nitrite, sulfate, carbonate, nitrate, and phosphate ion content. The results of the analyses were used to develop simulated pore solutions. Selected grouts and simulated pore solutions were paired to evaluate their potential to cause corrosion of, respectively, grout-wrapped and bare stress-relieved seven-wire prestressing strands using the rapid macrocell test. Strands were also evaluated in simulated pore solutions containing chlorides and in deionized water.

Based on the results presented in this report, the following conclusions may be drawn:

1. Leaving prestressing strands unprotected from the elements has the potential to result in rapid corrosion of the exposed strands.

2. The gypsum grout has a significantly lower $\mathrm{pH}$ than any of the other grouts tested. It also has a higher sulfate content than all but one of the grouts. Gypsum will cause accelerated corrosion of strands when used in conjunction with portland cement grout or any of the commercially prepackaged grouts tested.

3. Corrosion of strands in commercially available prepackaged grouts increases as the sulfate ion content of the grout pore solution increases. 
4. When paired with portland cement grout, the prepackaged anti-bleed grouts evaluated in this study resulted in corrosion losses significantly below those observed for strands exposed to salt or water. The highest corrosion measured for a prepackaged grout in conjunction with portland cement grout occurred for the grout with the highest pore solution sulfate content.

\section{RECOMMENDATIONS}

1. Because exposure of strands to water or chlorides can cause rapid corrosion, it is recommended that voids in post-tensioning ducts be filled with an anti-bleed grout.

2. The anti-bleed grout should be selected to minimize environmental differences with the existing grout that could result in accelerated corrosion of the post-tensioning strands. In addition to $\mathrm{pH}$, the sulfate ion concentration of the commercial grout pore solution should be monitored. For repairs to ducts containing portland cement grout, the four commercially available grouts evaluated in this study provided significant reduction in corrosion compared to strands exposed to salt or water. The use of grouts with high gypsum content should be avoided in post-tensioning applications.

\section{REFERENCES}

Al-Moudi, O. S. B., 1994, "Influence of Sulfate Ions on Chloride-Induced Reinforcement Corrosion in Portland and Blended Cement Concretes," Cement, Concrete and Aggregates, V. 16, Issue 1, June, pp. 3-11.

Al-Moudi, O. S. B., 2007, "Protection of Reinforced Concrete Structures in Chloride-Sulfate Exposures," Corrosion 2007, NACE, Report No. 279, pp. 072791-0727916.

ASTM A416, 2010, "Standard Specification for Steel Strand, Uncoated Seven-Wire for Prestressed Concrete (ASTM A416/A416M-10)," ASTM International, West Conshohocken, PA, 5 pp. 
ASTM A955, 2010, "Standard Specification for Plain and Deformed Stainless-Steel Bars for Concrete Reinforcement (ASTM A955/A955M-10)," ASTM International, West Conshohocken, PA, $11 \mathrm{pp}$.

Barneyback, R. and Diamond, S., 1981, "Expression and Analysis of Pore Fluids from Hardened Cement Pastes and Mortars," Cement and Concrete Research, Vol. 11, No. 2, Mar., pp. 279-285.

Ji, J., Darwin, D., and Browning, J., 2005, "Corrosion Resistance of Duplex Stainless Steels and MMFX Microcomposite Steel for Reinforced Concrete Bridge Decks," SM Report No. 80, University of Kansas Center for Research, Inc., Lawrence, Kansas, Dec., 453 pp.

Jones, D., 1996, Principles and Prevention of Corrosion, Upper Saddle River, NJ, Prentice Hall, $572 \mathrm{pp}$.

Lambert, P., Page, C. L., and Vassie, P. R. W., 1991, "Investigation of Reinforcement Corrosion. 2. Electrochemical Monitoring of Steel in Chloride contaminated Concrete," Materials and Structures, Vol. 24, No. 143, pp. 351-358.

McDonald, D. B., Pfeifer, D. W., and Sherman, M. R., 1998, "Corrosion Evaluation of EpoxyCoated, Metallic-Clad and Solid Metallic Reinforcing Bars in Concrete," Publication No. FHWA-RD-98-153, Federal Highway Administration, McLean, VA, 127 pp.

O'Reilly, M., Darwin, D., Browning, J.P., and Locke, Jr., C. E., 2011, "Evaluation of Multiple Corrosion Protection Systems for Reinforced Concrete Bridge Decks," SM Report No. 100, University of Kansas Center for Research, Inc., Lawrence, Kansas, Jan., 535 pp.

PB Americas, 2010, "US-54 CBD Viaducts Limited Site Investigation," Parts 1.3 and 1.4, Final Report, 130 pp.

Shi, J. and Sun, W., 2011, "Effect of Sulfate Ions on the Corrosion Behavior of Steel in Concrete Using Electrochemical Methods," Advanced Materials Research, V. 163-167, pp. 3049-3054.

Sturgeon, W.J., O'Reilly, M., Darwin, D., and Browning, J.P., 2010, "Rapid Macrocell Tests of ASTM A775, A615, and A1035 Reinforcing Bars," SL Report 10-4, University of Kansas Center for Research, Inc., Lawrence, Kansas, Nov., 46 pp.

Turkman, I. and Gavgali, M., 2003, "Influence of Mineral Admixtures on the Some Properties and Corrosion of Steel Embedded in Sodium Sulfate Solution of Concrete," Material Letters, V. 57, No. 21, pp. 3222-3233.

Xing, L., Darwin, D., and Browning, J.P., 2010, "Evaluation of Multiple Corrosion Protection Systems and Corrosion Inhibitors for Reinforced Concrete Bridge Decks," SM Report No. 99 , University of Kansas Center for Research, Inc., Lawrence, Kansas, May 2010, 507 pp. 